\title{
Regulation of Long-Term Depression and Climbing Fiber Territory by Glutamate Receptor $\delta 2$ at Parallel Fiber Synapses through its C-Terminal Domain in Cerebellar Purkinje Cells
}

\author{
Takeshi Uemura, ${ }^{1}$ Sho Kakizawa, ${ }^{2}$ Miwako Yamasaki, ${ }^{3}$ Kenji Sakimura, ${ }^{4}$ Masahiko Watanabe, ${ }^{3}$ Masamitsu Iino, ${ }^{2}$ and \\ Masayoshi Mishina ${ }^{1}$ \\ Departments of ${ }^{1}$ Molecular Neurobiology and Pharmacology and ${ }^{2}$ Molecular and Cellular Pharmacology, Graduate School of Medicine, University of Tokyo, \\ Tokyo 113-0033, Japan, ${ }^{3}$ Department of Anatomy, Hokkaido University Graduate School of Medicine, Sapporo 060-8638, Japan, and ${ }^{4}$ Department of \\ Cellular Neurobiology, Brain Research Institute, Niigata University, Niigata 951-8585, Japan
}

\begin{abstract}
Glutamate receptor (GluR) $\delta 2$ selectively expressed in cerebellar Purkinje cells (PCs) plays key roles in long-term depression (LTD) induction at parallel fiber (PF)-PC synapses, motor learning, the matching and connection of PF-PC synapses in developing and adult cerebella, the elimination of multiple climbing fibers (CFs) during development, and the regulation of CF territory on PCs. However, it remains unsolved how GluR $\delta 2$ regulates cerebellar synaptic plasticity, PF-PC synapse formation, and CF wiring. One possible signaling mechanism through GluR $\delta 2$ is signaling by protein-protein interactions. The C-terminal region of GluR $\delta 2$ contains at least three domains for protein-protein interactions. The PDZ (postsynaptic density-95/Discs large/zona occludens 1)-binding domain at the C terminal, named as the T site, interacts with several postsynaptic density proteins. Here, we generated GluR $\delta 2 \Delta \mathrm{T}$ mice carrying mutant GluR $\delta 2$ lacking the $T$ site. There were no significant differences in the amount of receptor proteins at synapses, histological features, and the fine structures of PF-PC synapses between wild-type and GluR $\delta 2 \Delta$ T mice. However, LTD induction at PF-PC synapses and improvement in the accelerating rotarod test were impaired in GluR $\delta 2 \Delta \mathrm{T}$ mice. Furthermore, CF territory expanded distally and ectopic innervation of CFs occurred at distal dendrites in GluR $\delta 2 \Delta \mathrm{T}$ mice, but the elimination of surplus $\mathrm{CF}$ innervation at proximal dendrites appeared to proceed normally. These results suggest that the C-terminal T site of GluR $\delta 2$ is essential for LTD induction and the regulation of $\mathrm{CF}$ territory but is dispensable for PF-PC synapse formation and the elimination of surplus CFs at proximal dendrites during development.
\end{abstract}

Key words: cerebellum; climbing fiber territory; glutamate receptor $\delta 2$; long-term depression; parallel fiber synapse; PDZ-binding domain

\section{Introduction}

The pattern of intrinsic neural connections in the cerebellum is known in considerable detail (Altman and Bayer, 1997). Various studies have suggested the important roles of the cerebellum in fine motor control and motor learning (Christian and Thompson, 2003; Boyden et al., 2004). These features make the cerebellum an ideal system for studying the molecular and cellular mechanisms of brain wiring and function. We found the $\delta$ subfamily of the glutamate

\section{Received June 13, 2007; revised Sept. 7, 2007; accepted Sept. 17, 2007.}

This work was supported in part by research grants from the Ministry of Education, Culture, Sports, Science, and Technology of Japan and Solution-Oriented Research for Science and Technology, the Japan Science and Technology Corporation. We thank Yoshinori Mikami, Dr. Hiroshi Sagara, and Joel Ju for help in preliminary experiments, Dr. Tomonori Takeuchi and Rie Natsume for help in mutant mouse generation, and Yuki Takahashi for mouse genotyping.

Correspondence should be addressed to Dr. Masayoshi Mishina, Department of Molecular Neurobiology and Pharmacology, Graduate School of Medicine, University of Tokyo, Tokyo 113-0033, Japan. E-mail: mishina@m.u-tokyo.ac.jp.

DOI:10.1523/JNEUROSCI.2680-07.2007

Copyright $\odot 2007$ Society for Neuroscience $\quad$ 0270-6474/07/2712096-13\$15.00/0 receptor (GluR) by molecular cloning (Yamazaki et al., 1992). From the amino acid sequence identity, the GluR $\delta$ subfamily positions between the classical AMPA/kainate and NMDA subtypes of GluR. The second member of this subfamily, GluR $\delta 2$, is selectively expressed in cerebellar Purkinje cells (PCs) (Araki et al., 1993; Lomeli et al., 1993). In PCs, GluR $\delta 2$ is exclusively localized at parallel fiber (PF)-PC synapses (Takayama et al., 1996; Landsend et al., 1997). Long-term depression (LTD) at PF-PC synapses, motor learning, and motor coordination are impaired in GluR $\delta 2$ mutant mice (Funabiki et al., 1995; Kashiwabuchi et al., 1995; Kishimoto et al., 2001). Furthermore, a significant number of PC spines lack synaptic contacts with PF terminals (Kashiwabuchi et al., 1995; Kurihara et al., 1997). In addition, multiple climbing fiber (CF) innervation to PCs is sustained and CF territory expands distally in GluR $\delta 2$ mutant mice (Kashiwabuchi et al., 1995; Hashimoto et al., 2001; Ichikawa et al., 2002). Inducible ablation of GluR $\delta 2$ has shown a key role of GluR $\delta 2$ in matching and connecting PF-PC synapses in the adult brain (Takeuchi et al., 2005). 
However, it remains unsolved how GluR $\delta 2$ regulates cerebellar synaptic plasticity, PF-PC synapse formation and CF wiring. There is no evidence for GluR $\delta 2$ channel activities, although lurcher mutation transformed GluR $\delta 2$ to constitutively active channels (Zuo et al., 1997). One possible signaling mechanism through GluR $\delta 2$ is signaling by protein-protein interactions. The C-terminal region of GluR $\delta 2$ contains at least three domains for protein-protein interactions (Roche et al., 1999; Uemura et al., 2004; Yawata et al., 2006). The PDZ [postsynaptic density (PSD)95/Discs large/zona occludens 1]-binding domain at the very end of the C terminal, designated as the T site, interacts with PSD-93, PTPMEG (protein tyrosine phosphatase), Delphilin, nPIST (Golgi-resident PDZ protein), and S-SCAM (synaptic scaffolding molecule) (Roche et al., 1999; Hironaka et al., 2000; Miyagi et al., 2002; Yue et al., 2002; Yap et al., 2003). In the middle of the $\mathrm{C}$-terminal region, there is the domain that interacts with Shank scaffold proteins, designated as the $\mathrm{S}$ segment (Uemura et al., 2004). The membrane-proximal domain of the C-terminal region of GluR $\delta 2$ interacts with protein interacting with $\mathrm{C}$ kinase 1 (Yawata et al., 2006). Here, we generated GluR $\delta 2 \Delta \mathrm{T}$ mice carrying mutant GluR $\delta 2$ lacking the T site to investigate the molecular mechanisms underlying diverse GluR $\delta 2$ functions. The $\mathrm{C}$ terminal truncation impaired LTD induction at PF-PC synapses and caused CF territory expansion but had little effect on PF-PC synapse formation and elimination of surplus CFs at proximal dendrites. These results suggest that signaling through the $\mathrm{T}$ site of GluR $\delta 2$ underlies the heterosynaptic competition between PF and $\mathrm{CF}$.

\section{Materials and Methods}

Generation of mutant mice with GluR $\delta 2$ lacking the C terminus. We identified a bacterial artificial chromosome (BAC) clone, RP23-37704 (BACPAC Resources Center, Oakland, CA) prepared from the C57BL/6 strain, carrying the C-terminal region of GluR $\delta 2$ using basic local alignment search tool searches against the mouse genome sequence database. The $11.9 \mathrm{~kb}$ genomic DNA fragment carrying exon 16 encoding the C-terminal region of GluR $\delta 2$ was introduced into the pMC1DTpA (Taniguchi et al., 1997) by Red/ET recombination using BAC subcloning kit (Gene Bridges, Dresden, Germany) to yield p $\delta 2-11.9$. Genomic DNA fragment carrying the exon 16 of GluR $\delta 2$ gene having a deletion of the 21 nucleotides encoding the $\mathrm{C}$-terminal 7 aa residues (T site) was prepared by PCR and introduced into $\mathrm{p} \delta 2-11.9$ by Red/ET recombination to yield $\mathrm{p} \delta 2-11.9 \Delta \mathrm{T}$. The $3.0 \mathrm{~kb}$ DNA fragment carrying phosphoglycerate kinase $P g k-1$ promoter-driven neomycin phosphotransferase gene (neo) and Tn5 promoter-driven chloramphenicol-acetyltransferase gene (cam) flanked by two Flp recognition target ( $f l p)$ sites was inserted into $1.6 \mathrm{~kb}$ downstream of exon 16 of $\mathrm{p} \delta 2-11.9 \Delta \mathrm{T}$ by Red/ET recombination to yield $\mathrm{pTV} \Delta \mathrm{T}$. The targeting vector $\mathrm{pTV} \Delta \mathrm{T}$ contained exon 16 having a deletion of the T site, neo and cam genes flanked by two frt, the $5.9 \mathrm{~kb}$ upstream and the $3.0 \mathrm{~kb}$ downstream genomic sequences, and $4.3 \mathrm{~kb}$ pMCDTpA. The targeting vector pTV $\Delta \mathrm{T}$ was linearized by NotI and electroporated into embryonic stem (ES) cell line RENKA derived from C57BL/6N strain (Mishina and Sakimura, 2007) as described previously (Takeuchi et al., 2005). G-418 (150 $\mu \mathrm{g} / \mathrm{ml})$-resistant clones were picked, and targeted clones were identified by Southern blot hybridization analysis using PCR-amplified 709 bp fragment, PCR-amplified 793 bp fragment, and $0.6 \mathrm{~kb}$ PstI fragment from pLFNeo (Takeuchi et al., 2002) as $5^{\prime}$, $3^{\prime}$, and neo probes, respectively. The $5^{\prime}$ probe and $3^{\prime}$ probes were amplified by PCR using $5^{\prime}$-CCATGGTTGCAGGGACGC- $3^{\prime}$ and $5^{\prime}$-CCATGGGAAGACTTTGGTTG-3'， 5'-AGATCTCCAAGAAAAAAGATAG-3' and $5^{\prime}$-GAATTCAGATTCATCTGCTTC- ${ }^{\prime}$ ' as primers, respectively. Recombinant ES cells were injected into eight-cell stage embryo of CD-1 mouse strain. The embryos were cultured to blastocysts and transferred to the pseudopregnant CD-1 mouse uterus. Resulting chimera mice were mated to C57BL/6N mice to yield heterozygous $\left(G l u R \delta 2^{+/ \Delta T}\right)$ mice. Homozygous GluR $\delta 2^{\Delta T / \Delta T}$ and GluR $\delta 2^{+/+}$mice were obtained by crossing heterozygous pairs. The GluR $\delta 2^{+/ \Delta T}$ allele was identified by PCR using primers 5'-GGCTCAATCTGGGCAATGAC-3' (P1) and 5'-AAATGGAGGGTGATAGACAGAG-3' (P2). Animal care was performed in accordance with institutional guidelines. Mice were fed ad libitum with standard laboratory chow and water in standard animal cages under a $12 \mathrm{~h} \mathrm{light/dark} \mathrm{cycle.} \mathrm{All} \mathrm{animal} \mathrm{procedures} \mathrm{were} \mathrm{approved} \mathrm{by} \mathrm{the} \mathrm{Animal}$ Care and the Use Committee of Graduate School of Medicine, the University of Tokyo (Approval number 1721T062), and the Animal Care and Use Committee of Hokkaido University (Approval number 17-96). For subsequent analyses, we used GluR $\delta 2^{+/+}$and GluR $\delta 2^{\Delta T / \Delta T}$ mice of 4 weeks old unless otherwise specified.

Western blot analysis. Homogenates and PSD fractions were prepared essentially according to the procedure as described previously (Carlin et al., 1980; Cho et al., 1992). Triton X-100-treated synaptosomes were centrifuged $(1 \mathrm{~h}, 70,000 \times g)$ to obtain the PSD fraction (Steigerwald et al., 2000). Proteins were separated by SDS-PAGE and analyzed by Western blot with anti-GluR 22 (Araki et al., 1993), anti-GluR 22 (C-19) (Santa Cruz Biotechnology, Santa Cruz, CA), anti-GluRe1 (Watanabe et al., 1998), or anti-neuron-specific enolase (NSE) (Chemicon, Temecula, CA) as described previously (Uemura et al., 2004). For quantitative analysis, signals were analyzed by LAS-1000plus image analyzer (Fujifilm, Tokyo, Japan) with Multi Gauge version 3.1 software (Fujifilm).

Histology and immunohistochemistry. Under deep pentobarbital anesthesia (100 $\mu \mathrm{g} / \mathrm{g}$ body weight, i.p.), mice were perfused transcardially with $4 \%$ paraformaldehyde in $0.1 \mathrm{~m}$ sodium phosphate buffer $(\mathrm{PB}), \mathrm{pH}$ 7.2, for immunohistochemistry and postembedding immunogold electron microscopy, or $2 \%$ paraformaldehyde $/ 2 \%$ glutaraldehyde in sodium cacodylate buffer, $\mathrm{pH}$ 7.2, for conventional electron microscopy. Sections were prepared with microslicer (VT1000S; Leica, Wetzlar, Germany) for immunofluorescence (50 $\mu \mathrm{m}$ in thickness) and for electron microscopy (400 $\mu \mathrm{m}$ in thickness). Sections were stained with guinea pig anti-vesicular glutamate transporter 2 (VGluT2) $(0.5 \mu \mathrm{g} / \mathrm{ml})$ antibody (Miyazaki et al., 2003) and rabbit anti-calbindin serum (1:10,000 dilution) (Nakagawa et al., 1998), followed by incubation with Alexa Fluor 488-conjugated (Invitrogen, Carlsbad, CA) and cyanine 3 (Cy3)conjugated (Jackson ImmunoResearch, West Grove, PA) secondary antibodies. Images of double immunofluorescence were taken with a confocal laser-scanning microscope (Radiance 2100; Bio-Rad, Hercules, CA). Paraffin sections (5 $\mu \mathrm{m}$ in thickness) were prepared with a sliding microtome (SM2000R; Leica). Paraffin sections were stained with hematoxylin or immunostained with goat anti-VGluT2 $(1 \mu \mathrm{g} / \mathrm{ml})$, guinea pig anti-calbindin $(1 \mu \mathrm{g} / \mathrm{ml})$ (Nakagawa et al., 1998), and rabbit antiGluR $\delta 2(1 \mu \mathrm{g} / \mathrm{ml}$ ) (Araki et al., 1993) antibodies or goat anti-VGluT1 (1 $\mu \mathrm{g} / \mathrm{ml}$ ) (Miura et al., 2006), guinea pig anti-calbindin $(1 \mu \mathrm{g} / \mathrm{ml}$ ), and rabbit anti-GluR $\delta 2(1 \mu \mathrm{g} / \mathrm{ml})$ antibodies, respectively, followed by incubation with species-specific Alexa Fluor 488-conjugated (Invitrogen), Cy3- and Cy5-conjugated (Jackson ImmunoResearch) secondary antibodies. Immunoperoxidase staining with anti-calbindin antibody was performed essentially as described previously (Nakagawa et al., 1998). Images of hematoxylin staining, immunoperoxidase staining, and triple immunofluorescence were taken with a fluorescence microscope (DM 2500; Leica) equipped with a CCD camera (DFC 480; Leica) and a confocal laser-scanning microscope (TCS SP5; Leica), respectively. The CFterminal reach and the thickness of the molecular layer were measured using NIH ImageJ 1.36b software. For a quantitative analysis, eight CFs and eight points of molecular layers in the straight portion of lobules $4 / 5$ per section were measured, and nine sections from nine mice for each genotype were analyzed.

Anterograde labeling. Under anesthesia with chloral hydrate (350 $\mathrm{mg} / \mathrm{kg}$ body weight, i.p.), a glass pipette (G-1.2; Narishige, Tokyo, Japan) filled with $2-3 \mu$ l of $10 \%$ solution of dextran Texas red (DTR) or biotinylated dextran amine (3000 molecular weight; Invitrogen) in PBS, pH 7.4, was inserted to the inferior olive by the dorsal approach. The tracer was injected by air pressure at 5 psi with $5 \mathrm{~s}$ intervals for $1 \mathrm{~min}$ (Pneumatic Picopump; World Precision Instruments, Tokyo, Japan). After $4 \mathrm{~d}$ of survival, mice were anesthetized and fixed by transcardial perfusion. DTR-labeled microslicer sections were further subjected to incubation with goat anti-calbindin antibody $(1 \mu \mathrm{g} / \mathrm{ml})$ or with a mixture of goat anti-calbindin antibody $(1 \mu \mathrm{g} / \mathrm{ml})$ and guinea pig anti-VGluT2 antibody 
$(0.5 \mu \mathrm{g} / \mathrm{ml})$ and finally with fluorescent secondary antibodies for $2 \mathrm{~h}$. Images of double or triple fluorescent labeling were taken with a confocal laser-scanning microscope (FV1000; Olympus Optical, Tokyo, Japan).

Conventional electron microscopy. For qualitative and quantitative analysis by electron microscopy, microslicer sections were postfixed with $1 \%$ osmium tetroxide in $0.1 \mathrm{~m}$ cacodylate buffer for $1 \mathrm{~h}$, stained in block with uranyl acetate, dehydrated in graded alcohols, and embedded in Epon 812. Ultrathin sections (70 nm in thickness) cut in the parasagittal plane were prepared from the straight portion of lobules $4 / 5$ using an Ultracut ultramicrotome (Leica). Serial ultrathin sections were mounted on Formvar-supported copper grids and stained with $2 \%$ uranyl acetate for $5 \mathrm{~min}$ and mixed leads solution for $2 \mathrm{~min}$. In each mouse, serial electron micrographs were sampled randomly from the neuropil of the molecular layer. Electron micrographs were taken at an original magnification of $4000 \times$ or $8000 \times$ using an electron microscope (H-7100; Hitachi High Technologies, Tokyo, Japan). For quantitative analysis, negative films of electron micrographs were scanned and analyzed with MetaMorph software (Molecular Devices, Sunnyvale, CA).

Postembedding immunogold electron microscopy. For postembedding immunogold electron microscopy, microslicer sections were cryoprotected with $30 \%$ glycerol in $0.1 \mathrm{M} \mathrm{PB}, \mathrm{pH} 7.4$, and frozen rapidly in liquid propane in a cryofixation unit (CPC; Leica). Frozen sections were transferred to $0.5 \%$ uranyl acetate in methanol in a cryosubstitution unit (AFS; Leica), embedded in Lowicryl HM20 resin (Electron Microscopy Sciences, Hatfield, PA), and polymerized with UV light. Ultrathin sections were mounted on nickel grids and etched with a saturated solution of $\mathrm{NaOH}$ in absolute ethanol for a few seconds. After blocking with $2 \%$ human serum albumin (Wako Pure Chemicals, Osaka, Japan) in $10 \mathrm{~mm}$ Tris-buffered saline (TBS), $\mathrm{pH} 7.6$, grids were immunoreacted with a mixture of rabbit anti-GluR $\delta 2(20 \mu \mathrm{g} / \mathrm{ml})$ and guinea pig anti-VGluT2 $(20 \mu \mathrm{g} / \mathrm{ml})$ antibodies overnight. After washing with TBS, grids were further incubated with a mixture of colloidal gold $(10 \mathrm{~nm})$-conjugated anti-rabbit IgG and colloidal gold $(20 \mathrm{~nm})$-conjugated anti-guinea pig IgG (British Biocell International, Cardiff, UK) for $2 \mathrm{~h}$. Finally, grids were stained with $2 \%$ uranyl acetate for $5 \mathrm{~min}$ and mixed lead solution for $30 \mathrm{~s}$. Electron micrographs were taken randomly by an H-7100 electron microscope at magnification of $10,000 \times$. For quantitative analysis, the number of metal particles and the length of postsynaptic density were measured on scanned electron micrographs with MetaMorph software (Molecular Devices).

Electrophysiology. Four-week-old male mice were killed by cervical dislocation under deep anesthesia with diethyl ether. The cerebellum was excised, and parasagittal cerebellar slices ( $250 \mu \mathrm{m}$ thick) were prepared from the vermis (Edwards et al., 1989; Kakizawa et al., 2000, 2005). Whole-cell recordings were obtained from visually identified PCs under an upright microscope (BX51WI; Olympus Optical) using a $40 \times$ waterimmersion objective at room temperature $\left(23-25^{\circ} \mathrm{C}\right)$. The resistances of patch pipettes were $2.0-3.5 \mathrm{M} \Omega$ when filled with an intracellular solution composed of the following (in $\mathrm{mm}$ ): $60 \mathrm{CsCl}, 10 \mathrm{Cs}$ D-gluconate, 20 tetraethylammonium (TEA)-Cl, 20 BAPTA, $4 \mathrm{MgCl}_{2}$, 4 ATP, 0.4 GTP, and 30 HEPES, adjusted to $\mathrm{pH} 7.3$ with $\mathrm{CsOH}$. The standard bathing solution was composed of the following (in $\mathrm{mm}$ ): $125 \mathrm{NaCl}, 2.5 \mathrm{KCl}, 2$ $\mathrm{CaCl}_{2}, 1 \mathrm{MgSO}_{4}, 1.25 \mathrm{NaH}_{2} \mathrm{PO}_{4}, 26 \mathrm{NaHCO}_{3}$, and 20 glucose (bubbled with $95 \% \mathrm{CO}_{2}$ and $\left.5 \% \mathrm{CO}_{2}\right)$. Bicuculline $(10 \mu \mathrm{M})$ was always added to block IPSCs. There were no significant differences in passive electrophysiological membrane properties in PCs (Llano et al., 1991) between wildtype and GluR $\delta 2 \Delta \mathrm{T}$ mice (data not shown). A stimulation pipette (5-10 $\mu \mathrm{m}$ in tip diameter) was filled with the standard bathing solution and used in applying square pulses $(0.1 \mathrm{~ms}$ in duration) for the focal stimulation of PFs $(0-20 \mathrm{~V}$ in amplitude) in the molecular layer at the deeper one-third from the pial surface or CFs in granular layer $(0-90 \mathrm{~V}$ in amplitude). Ionic current was recorded from PCs with a patch-clamp amplifier (EPC-9; HEKA Elektronik, Lambrecht/Pfalz, Germany) at a holding potential of -90 or $-80 \mathrm{mV}$ (for PF-EPSC) or -20 or $-10 \mathrm{mV}$ (for CF-EPSC), after the compensation of liquid junction potential. The signals were filtered at $2 \mathrm{kHz}$ and digitized at $20 \mathrm{kHz}$. On-line data acquisition and off-line data analysis were performed using PULSE (HEKA Elektronik) software. For the LTD experiment (see Fig. 5C), a pipette solution with the following composition was used (in $\mathrm{mm}$ ): $60 \mathrm{CsCl}, 40$
Cs D-gluconate, 20 TEA-Cl, 1 EGTA, $4 \mathrm{MgCl}_{2}$, 4 ATP, 0.4 GTP, and 30 HEPES, adjusted to $\mathrm{pH} 7.3$ with $\mathrm{CsOH}$. LTD was induced by conjunctive stimulation (PF stimuli concomitant with $50 \mathrm{~ms}$ depolarizations of the PC to $0 \mathrm{mV}$ at $1 \mathrm{~Hz}, 300$ pulses) after the acquisition of baseline responses (Fujiwara et al., 2007). Test stimulus was applied to PF every $10 \mathrm{~s}$. The amplitude of PF-EPSC was averaged every $60 \mathrm{~s}$ and normalized to the mean value observed for $10 \mathrm{~min}$ before an LTD-inducing stimulus. A 100 $\mathrm{ms},-5 \mathrm{mV}$ hyperpolarizing test pulse preceded each PF stimulus to monitor the series resistance and input resistance of PCs throughout the experiment, the data of which were discarded if the resistance changed by $>10 \%$ (Namiki et al., 2005; Kakizawa et al., 2007). The data were also discarded when the slope of PF-EPSC amplitude averaged every minute during the initial recording for 10 min was larger than $2 \%$ or when the amplitude did not become stable within $30 \mathrm{~min}$ after the onset of wholecell configuration (Namiki et al., 2005; Kakizawa et al., 2007).

Motor behavioral test. The accelerating rotarod apparatus consisted of a 3.2-cm-diameter rod (RRAC-3002; O'Hara \& Company, Tokyo, Japan) was used to measure motor coordination. The rotarod test was performed essentially according to the procedure described previously (Nolan et al., 2003). Male mice of 5 weeks old were used for motor behavioral test. During the training period, mice were placed on the rotating rod starting at $5 \mathrm{rpm}$ and gradually accelerated to $50 \mathrm{rpm}$ at a rate $0.15 \mathrm{rpm} / \mathrm{s}$. The latency to fall (retention time) was measured with cutoff time of $5 \mathrm{~min}$. Mice were trained for 3 consecutive days, receiving four trials per day with a $1 \mathrm{~h}$ intertrial interval.

Statistical analysis. Statistical significance was evaluated by one-way ANOVA or two-way ANOVA. When the interaction was significant, Student's $t$ test or Scheffé's post hoc test was used. Statistical significance was assumed when $p<0.05$.

\section{Results}

Generation of GluR $\delta 2 \Delta \mathrm{T}$ mice carrying C terminal-truncated GluR $\delta 2$ on pure C57BL/6 genetic background

To investigate the molecular basis of the multiple and diverse functions of GluR $\delta 2$, we generated mice with mutant GluR $\delta 2$ lacking the $\mathrm{C}$ terminal. The targeting vector carried the mutant GluR $\delta 2 \Delta T$ gene with a deletion of the $21 \mathrm{nt}$ sequence encoding the C-terminal 7 aa residues (T site) (Fig. $1 A$ ). We obtained recombinant GluR $\delta 2^{+/ \Delta T}$ mice (Fig. $1 B, C$ ) by homologous recombination in ES cells derived from the C57BL/6 strain (Mishina and Sakimura, 2007). Crossing of heterozygous GluR $\delta 2^{+/ \Delta T}$ mice with each other yielded homozygous GluR $\delta 2^{\Delta T / \Delta T}$ mice, designated as GluR $\delta 2 \Delta \mathrm{T}$ mice (Fig. $1 B, C$ ). The mutant mice grew normally with no obvious ataxic gaits. Subsequent analyses were performed with 4-week-old GluR $\delta 2 \Delta \mathrm{T}$ mice unless otherwise specified, and wild-type offspring of heterozygous intercrosses served as controls.

The expression level of truncated GluR $\delta 2 \Delta \mathrm{T}$ in cerebellar homogenates was examined by Western blot analysis using antibody against amino acid residues 837-916 of GluR $\delta 2$ (Araki et al., 1993). This antigenic sequence does not include the C-terminal 76 aa. Thus, the antibody is expected to react with both GluR $\delta 2$ and GluR $\delta 2 \Delta \mathrm{T}$ at similar potencies. The amount of GluR $\delta 2 \Delta \mathrm{T}$ in mutant mice was $76.3 \pm 3.0 \%$ (mean \pm SEM; $n=6$ ) of GluR $\delta 2$ in wild-type mice as estimated by comparing that of NSE as an internal standard (Fig. 2A). This value was higher than the expression level of GluR $\delta 2$ in GluR $\delta 2^{+/ C r e P R}$ mice $(61.9 \pm 1.2 \%$, $n=6 ; p=0.0089$, Scheffé's test), in which one of the GluR $\delta 2$ alleles was disrupted by inserting the CrePR gene (Takeuchi et al., 2005). Previous studies showed that PF-PC synaptic structures of $G l u R \delta 2^{+/ C r e P R}$ mice are indistinguishable from those of wild-type mice (Takeuchi et al., 2005). As expected, antibody against the very end of the GluR $\delta 2$ C-terminal domain detected no GluR $\delta 2 \Delta \mathrm{T}$ (Fig. $2 B$ ). The amount of GluR $\delta 2 \Delta \mathrm{T}$ in the PSD fraction from mutant mice was comparable with that of GluR $\delta 2$ from wild-type mice $(87.6 \pm 10.3 \% ; n=6 ; p=0.32, t$ test $)$ as estimated 




Figure 1. Generation of GluR $\delta 2 \Delta \mathrm{T}$ mutant mice by homologous recombination in ES cells derived from the $\mathrm{C} 57 \mathrm{BL} / 6 \mathrm{strain}$. $\boldsymbol{A}$, Schematic representation of GluR $\delta 2$ CDNA, the GluR $\delta 2$ gene, targeting vector, and targeted gene. Relevant restriction enzyme sites are indicated. BSK, plasmid pBluescript; Cam, chloramphenicol-acetyltransferase gene; DT, diphtheria toxin gene; M1-M4, four putative transmembrane segments; Neo, neomycin phosphotransferase gene; SP, putative signal peptide; T site, C-terminal $\mathrm{PDZ}$ domain recognition site; El, EcoRl; EV, EcoRV. Gray shadow boxes indicate exons. Hatched bars indicate the location of probes for Southern blot analysis (probe 5', $3^{\prime}$, and Neo). Arrows indicate PCR primers (P1 and P2). B, Southern blot analysis of genomic DNA from GluR $\delta 2^{+/+}(+/+)$, GluR $\delta 2^{+/ \Delta T}(+/ \Delta T)$, and GluR $\delta 2^{\Delta T / \Delta T}(\Delta T / \Delta T)$ mice. Left, EcoRI-digested DNA hybridized with 3' probe; middle, EcoRl-digested DNA hybridized with Neo probe; right, EcoRV-digested DNA hybridized with 5' probe. $\boldsymbol{C}$,

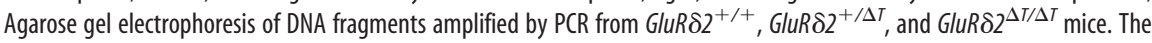
amplified DNA fragments derived from the wild-type and truncated GluR $\delta 2$ genes were 232 and $211 \mathrm{bp}$, respectively.

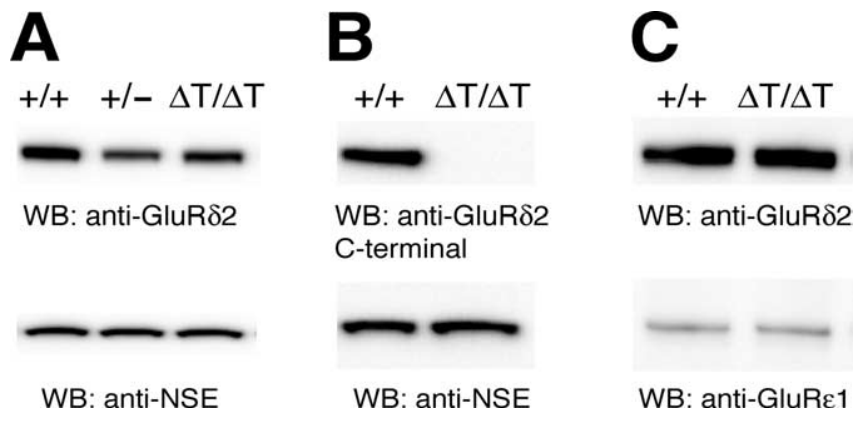

Figure 2. Expression of GluR $\delta 2 \Delta T$ in the cerebellum. $A$, Cerebellar homogenates from

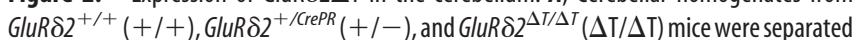
by SDS-PAGE and immunoblotted with anti-GluR $\delta 2$ and anti-NSE antibodies, respectively. $\boldsymbol{B}$, Cerebellar homogenates from wild-type and GluR $\delta 2 \Delta$ T mice were separated by SDS-PAGE and immunoblotted with antibody against the most C-terminal domain of GluR $\delta 2$ and anti-NSE antibody, respectively. C, PSD fractions from wild-type and GluR $\delta 2 \Delta T$ mice were separated by SDS-PAGE and immunoblotted with anti-GluR $\delta 2$ and anti-GluR $\varepsilon 1$ antibodies, respectively. WB, Western blot.

by comparing that of NMDA receptor GluR $\varepsilon 1$ that is expressed in cerebellar granule cells but not in PCs (Yamada et al., 2001) as an internal standard (Fig. 2C).
Histological features of the cerebellum

The foliation and laminar organization of the cerebellum were indistinguishable between wild-type and GluR $\delta 2 \Delta \mathrm{T}$ mice (Fig. $3 A, B)$. The arborization of $\mathrm{PC}$ dendrites was also comparable as revealed by immunostaining with anti-calbindin antibody (Fig. $3 A, B$ ). VGluT1 is predominantly expressed in PF terminals (Fremeau et al., 2001). Double immunostaining for GluR $\delta 2$ and VGluT1 showed numerous punctate signals in the molecular layer of both wild-type and GluR $\delta 2 \Delta \mathrm{T}$ mice (Fig. $3 C, D)$. Thus, there were no detectable differences in the histological features of the cerebellum between wild-type and GluR $\delta 2 \Delta \mathrm{T}$ mutant mice.

Fine structures of PF-PC synapses

The ablation of GluR $\delta 2$ hinders PF-PC synapse formation, resulting in the appearance of free spines and mismatched synapses in a substantial fraction of PC spines (Kashiwabuchi et al., 1995; Kurihara et al., 1997; Lalouette et al., 2001; Takeuchi et al., 2005). Thus, we further examined the fine structures of PF-PC synapses in wild-type and GluR $\delta 2 \Delta \mathrm{T}$ mice by electron microscopy. In both genotypes, most synapses in the molecular layer were asymmetrical synapses between presynaptic terminals containing round clear vesicles and postsynaptic dendritic spines with thickened PSDs; they were identified as PF-PC synapses from their characteristic morphology (Fig. 4A, B). When quantified on randomly taken electron micrographs, the numbers of PF-PC synapses per $100 \mu \mathrm{m}^{2}$ were $21.2 \pm 0.83$ for wildtype mice (mean \pm SEM; $n=1641,3$ animals) and $20.1 \pm 1.6$ for GluR $\delta 2 \Delta$ T mice ( $n=1827,3$ animals), showing no significant difference $(p=0.58)$.

We further examined the fine structures of PF-PC synapses by serial electron microscopy on randomly sampled PC spines. Most of these spines protruded from distal dendrites, which were $<2$ $\mu \mathrm{m}$ in caliber, abundant in mitochondria, and enclosed by ruffled cell membrane (Ichikawa et al., 2002). Only 1 of 513 spines counted from three GluR $\delta 2 \Delta \mathrm{T}$ mice was a free spine, resulting in high synaptic contact ratio $(99.8 \pm 0.19 \%)$. This value was not significantly different from that of wild-type mice $(100 \pm 0 \%$; $n=486,3$ animals; $p=0.42$ ). For quantitative comparison, we defined the mismatched synapse when the edges of the active zone and PSD were $>100 \mathrm{~nm}$ apart in any of its serial sections (Takeuchi et al., 2005). Under this criterion, we found that almost all the PC spines were matched synapses in both wild-type (99.4 $\pm 0.38 \% ; n=486,3$ animals) and GluR $\delta 2 \Delta \mathrm{T}$ (98.9 \pm $0.36 \% ; n=513,3$ animals) mice, showing no significant difference $(p=0.47)$. Thus, no structural abnormalities of PF-PC synapses were found in GluR $\delta 2 \Delta \mathrm{T}$ mice. We also examined the spine density at proximal dendrites of PCs because hyperspiny transformation was observed in voltage-dependent $\mathrm{Ca}^{2+}$ channel (VDCC) $\alpha 1 \mathrm{~A}$ mutant mice exhibiting abnormalities in the territory of PF-PC synapses (Miyazaki et al., 2004). There was no 
significant difference in the number of spines per micrometer of proximal dendrites ( $>2 \mu \mathrm{m}$ in caliber) between wildtype $(0.95 \pm 0.26$ calculated from $782 \mu \mathrm{m}$ of dendrites $)$ and GluR $\delta 2 \Delta \mathrm{T}(0.74 \pm 0.13$ calculated from $882 \mu \mathrm{m}$ ) mice (three animals each).

\section{Localization of GluR $\delta 2 \Delta \mathrm{T}$ at PF-PC synapses}

We examined the synaptic localization of GluR $\delta 2 \Delta \mathrm{T}$ by postembedding double immunogold using anti-GluR $\delta 2$ and antiVGluT2 antibodies. At PF-PC synapses of both wild-type and GluR $\delta 2 \Delta \mathrm{T}$ mice, small gold particles (diameter, $10 \mathrm{~nm}$ ) accumulated exclusively in PSD (Fig. 4C,E), indicating the selective localization of GluR $\delta 2 \Delta \mathrm{T}$ at the postsynaptic site. The labeling density per micrometer of PSD was determined by measuring the total number of gold particles and the length of PSD at a given synapse. There was no significant difference in mean labeling density between wild-type (32.5 \pm 1.1 particles/ $\mu \mathrm{m} ; n=119,3$ animals) and GluR $\delta 2 \Delta \mathrm{T}$ (32.6 \pm 1.2 particles $/ \mu \mathrm{m} ; n=130,3$ animals) mice $(p=0.97)$. We also examined the localization of GluR $\delta 2 \Delta \mathrm{T}$ at CF-PC synapses by identifying the CF terminals by VGluT2 labeling (large particles; diameter, $20 \mathrm{~nm}$ ) (Fig. $4 D, F)$. GluR $\delta 2$ gold particles were hardly detectable at CF-PC synapses in both genotypes. There was no significant difference in mean labeling density between wild-type $(2.0 \pm 0.5$ particles $/ \mu \mathrm{m} ; n=53,3$ animals $)$ and GluR $\delta 2 \Delta \mathrm{T}(2.4 \pm 0.4$ particles $/ \mu \mathrm{m} ; n=52,3$ animals $)$ mice $(p=$ 0.64 ) (Fig. $4 G$ ). Little effect of the C-terminal truncation on the postsynaptic localization of GluR $\delta 2$ is consistent with previous observations that mutant GluR $\delta 2$ lacking the C-terminal 986992 aa was efficiently localized at the membrane in cultured cells and at the synapse in cultured PCs and cerebellar slices (Matsuda and Mishina, 2000; Yawata et al., 2006; Kohda et al., 2007). In contrast, the deletion of the $\mathrm{C}$-terminal region disturbed the efficient synaptic localization of NMDA receptor GluRe2/NR2B in the hippocampal CA1 region and cultured neurons (Mori et al., 1998; Mohrmann et al., 2002). The apparent discrepancy may be ascribed to the size of deletion because the $\mathrm{C}$-terminal truncation was much larger in GluRe2 than in GluR $\delta 2$. Consistent with this notion, the membrane-proximal segment in the C-terminal region is essential for the efficient membrane localization of

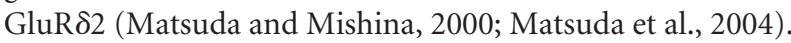

\section{Impairments of LTD induction at PF-PC synapses and improvement in accelerating rotarod test}

We examined synaptic transmission at PF-PC synapses in GluR $\delta 2 \Delta$ T mice by stimulating PFs at different intensities and by plotting the amplitude of PF-EPSCs as a function of stimulus intensity. As shown in Figure 5A, there was no significant difference in the slope of the amplitude-intensity curve between wildtype and GluR $\delta 2 \Delta \mathrm{T}$ PCs $(p=0.34, t$ test $)$. We also examined paired-pulse ratio (PPR), an index of change in transmitter release probability at presynaptic terminals (Zucker and Regehr, 2002). When the interpulse interval was within 10-300 ms, the PF-EPSCs of wild-type and GluR $\delta 2 \Delta \mathrm{T}$ mice displayed prominent facilitation in response to the second stimuli of paired pulses
(Fig. 5B), as reported previously in wild-type rats (Konnerth et al., 1990). The PPRs of PF-EPSC in GluR $\delta 2 \Delta$ T mice were slightly higher than those in wild-type mice at shorter interpulse intervals (Fig. 5B).

We then examined LTD at PF-PC synapses. After stable recordings of PF-EPSCs for $10 \mathrm{~min}$, LTD was induced by a conventional conjunction protocol, which consisted of 300 single PF stimuli in conjunction with a depolarizing pulse repeated at $1 \mathrm{~Hz}$ (Fujiwara et al. 2007). In wild-type mice, LTD was readily induced by conjunctive stimulation (Fig. 5C). Twenty-one to 30 min after conditioning, the mean amplitude of PF-EPSCs was reduced to $68.7 \pm 3.6 \%$ (mean \pm SEM) of the control value measured before conjunctive stimulation. However, the same conjunctive stimulation failed to induce LTD in GluR $\delta 2 \Delta$ T mice. The mean PF-EPSC amplitude 21-30 min after conditioning in GluR $\delta 2 \Delta \mathrm{T}$ mice $(106.0 \pm 5.4 \%)$ was significantly higher than that in wild-type mice ( $p=4.4 \times 10^{-5}$, Student's $t$ test) (Fig. $5 C)$. Thus, the T site of GluR $\delta 2$ is indispensable for LTD induction at PF-PC synapses.

GluR $\delta 2 \Delta \mathrm{T}$ mice showed no ataxic gait and could walk along a straight line, as wild-type mice did. The footprint pattern of GluR $\delta 2 \Delta \mathrm{T}$ mice was indistinguishable from that of wild-type mice (Fig. 6A). In the accelerating rotarod test (Crawley, 2000), wild-type and GluR $\delta 2 \Delta \mathrm{T}$ mice performed equally well in the first training session $(p=0.44)$ (Fig. $6 B$ ). In subsequent sessions, both wild-type and GluR $\delta 2 \Delta \mathrm{T}$ mice showed gradual increases in retention time on the rod during training. However, there was a significant difference in the retention time between two genotypes (ANOVA with repeated measures: genotype effect, $F_{(1,46)}=$ $19.5, p=6.1 \times 10^{-5}$; genotype $\times$ session interaction, $F_{(11,506)}=$ 2.22, $p=0.012$ ), suggesting that the improvement in performance was impaired in GluR $\delta 2 \Delta \mathrm{T}$ mice.

\section{Distal extension of CF territory}

GluR $\delta 2$ null mutation affects the innervation patterns of CFs to PCs (Kashiwabuchi et al., 1995; Ichikawa et al., 2002). We thus examined CF innervation patterns in GluR $\delta 2 \Delta \mathrm{T}$ mice by immunostaining for VGluT2, which is predominantly expressed in CF 

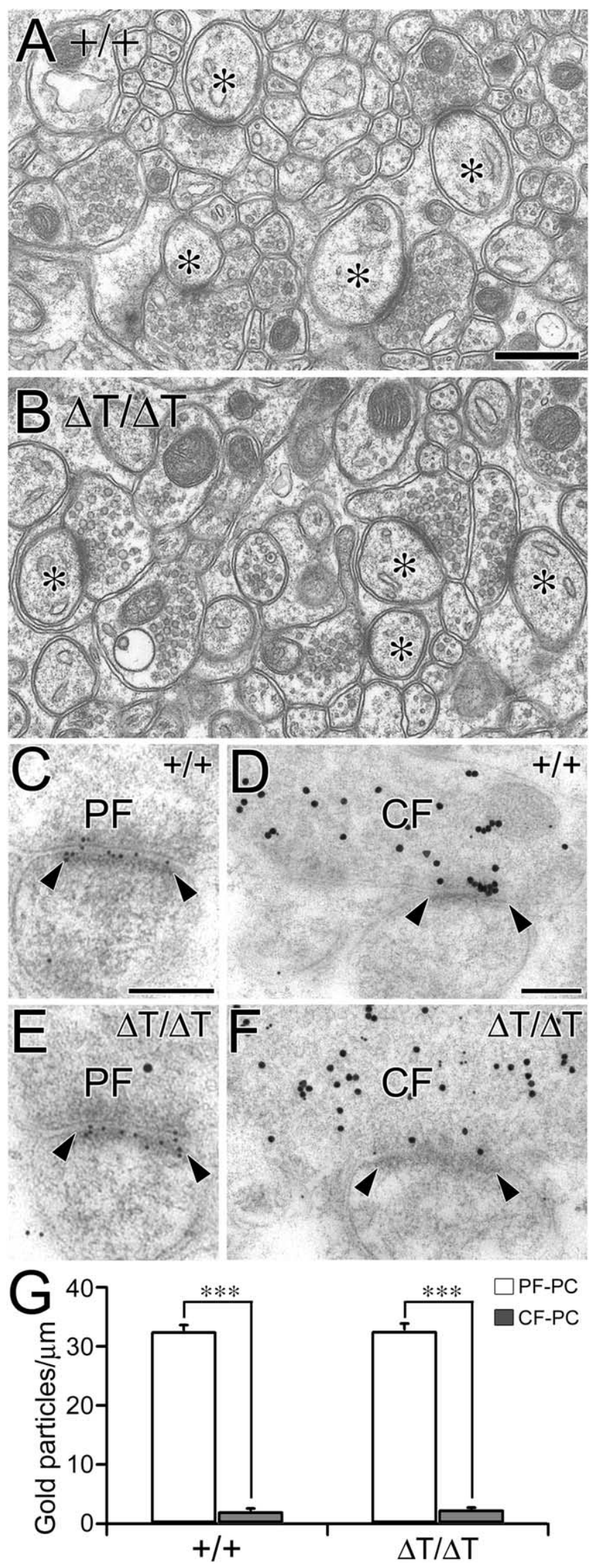

Figure 4. Structure of PF-PC synapses and localization of GluR $\delta 2 \Delta T$ at $P F-P C$ synapses in mutant mice. $\boldsymbol{A}, \boldsymbol{B}$, Electron micrographs showing the fine structure of PF-PC synapses in wild-type $(+/+)(A)$ and GluR $\delta 2 \Delta \mathrm{T}(\Delta \mathrm{T} / \Delta \mathrm{T})(\boldsymbol{B})$ mice. Asterisks indicate the head of $\mathrm{PC}$ spines forming asymmetric synapse with PF axon terminals. $\mathbf{C}-\boldsymbol{F}$, Postembedding double terminals (Fremeau et al., 2001). The VGluT2 immunostaining signals in the molecular layer of GluR $\delta 2 \Delta \mathrm{T}$ mice were more expanded toward the superficial region than those in the case of wild-type mice (Fig. 7A). CFs grow upward in the molecular layer along expanding PC dendritic arbors (Altman and Bayer, 1997). The thickness of the molecular layer in wild-type mice significantly increased from postnatal day 16 (P16) to P29-P31 (oneway ANOVA, $\left.F_{(2,24)}=27.0, p=7.2 \times 10^{-7}\right)($ Fig. $7 B, C)$. The thicknesses of the molecular layer were comparable between GluR $\delta 2 \Delta \mathrm{T}$ and wild-type mice (two-way ANOVA: genotype effect, $F_{(1,48)}=1.13, p=0.29$; age $\times$ genotype interaction, $F_{(2,48)}=$ $0.442, p=0.65$ ) (Fig. $7 B, C$ ). Then, we analyzed the developmental changes of the distal extension of CF innervation by measuring the CF-terminal reach defined as the vertical height of the most distal tip of continuous VGluT2 immunostaining signals along the dendritic tree of single PCs from the bottom of the molecular layer. From P16 to P29-P31, CF-terminal reach value gradually increased in both genotypes. However, there was a significant difference in CF-terminal reach value between wild-type and GluR $\delta 2 \Delta \mathrm{T}$ mice (two-way ANOVA: genotype effect, $F_{(1,48)}=$ 26.6, $p=4.7 \times 10^{-6}$; age $\times$ genotype interaction, $F_{(2,48)}=5.59$, $p=0.0066$ ) (Fig. $7 B, C$ ). At P29-P31, the CF-terminal reach value in GluR $\delta 2 \Delta \mathrm{T}$ mice was significantly larger than that in wild-type mice ( $t$ test, $p=1.6 \times 10^{-5}$ ). We also analyzed the $\mathrm{CF}$ innervation territory by measuring the ratio of CF-terminal reach to molecular layer thickness during development. There was a significant difference in the CF innervation territory between wild-type and GluR $\delta 2 \Delta$ T mice (two-way ANOVA: genotype effect, $F_{(1,48)}=88.1, p=1.9 \times 10^{-12}$; age $\times$ genotype interaction, $F_{(2,48)}=18.0, p=1.5 \times 10^{-6}$ ) (Fig. $\left.7 B, C\right)$. In GluR $\delta 2 \Delta$ T mice, CF innervation territory was significantly larger than that in wildtype mice at P21 and P29-P31 ( $t$ test, $p=5 \times 10^{-5}$ and $2.1 \times$ $10^{-10}$, respectively). These results suggest that the territory of $\mathrm{CF}$ innervation along the PC dendritic trees is expanded in GluR $\delta 2 \Delta \mathrm{T}$ mice, despite the absence of any detectable structural abnormalities at PF-PC synapses.

\section{Ectopic CF innervation at distal dendrites}

We further examined CF innervation patterns by anterograde CF labeling with DTR (red), combined with immunofluorescence for VGluT2 (green) and calbindin (blue) (Figs. 8, 9). DTRlabeled CFs in GluR $\delta 2 \Delta \mathrm{T}$ mice extended their terminals more closely to the pial surface than those in wild-type mice (supplemental Fig. $1 A, B$, available at www.jneurosci.org as supplemental material), suggesting the expansion of the CF innervation territory.

In wild-type mice, proximal dendrites of given PCs were innervated by either DTR/VGluT2-double-labeled CFs (hereafter termed as CF1) (Fig. 8A, B, PC1) or VGluT2-single-labeled CFs (CF2) (Fig. 8A, $B$, PC2). Accordingly, almost all CF terminals along PC1 dendrites became white or yellow, whereas those along PC2 dendrites remained green or light blue, suggesting that the

$\leftarrow$

immunogold using anti-GluR $\delta 2$ antibody raised against amino acid residues 837-916 and anti-VGluT2 antibody. $\boldsymbol{C}, \boldsymbol{E}, \mathrm{PF}-\mathrm{PC}$ synapses of wild-type $(\boldsymbol{C})$ and $\mathrm{GluR} \delta 2 \Delta \mathrm{T}(\boldsymbol{E})$ mice. Arrowheads indicate the edge of PSD. GluR $\delta 2 \Delta T$ accumulates in PSD, in a similar manner with GluR $\delta 2$ in PSD of wild-type synapses. D, F, CF-PC synapses of wild-type $(\boldsymbol{D})$ and $G l u R \delta 2 \Delta \mathrm{T}(\boldsymbol{F})$ mice. CF terminals are intensively labeled for VGluT2 (large particles, $20 \mathrm{~nm}$ ). In clear contrast to PF-PC synapses, small GluR $\delta 2$ particles $(10 \mathrm{~nm})$ are hardly detectable at $\mathrm{CF}-\mathrm{PC}$ synapses of both genotypes. Arrowheads indicate the edge of PSD. G, The labeling density of GluR $\delta 2$ particles per $1 \mu \mathrm{m}$ of PSD at PF and CF synapses in wild-type and GluR $\delta 2 \Delta \mathrm{T}$ mice. Scale bars: $A, 500$ $\mathrm{nm} ; \boldsymbol{C}, \boldsymbol{D}, 100 \mathrm{~nm}$. All values represent mean \pm SEM. ${ }^{* * *} p<0.001$, Student's $t$ test. 


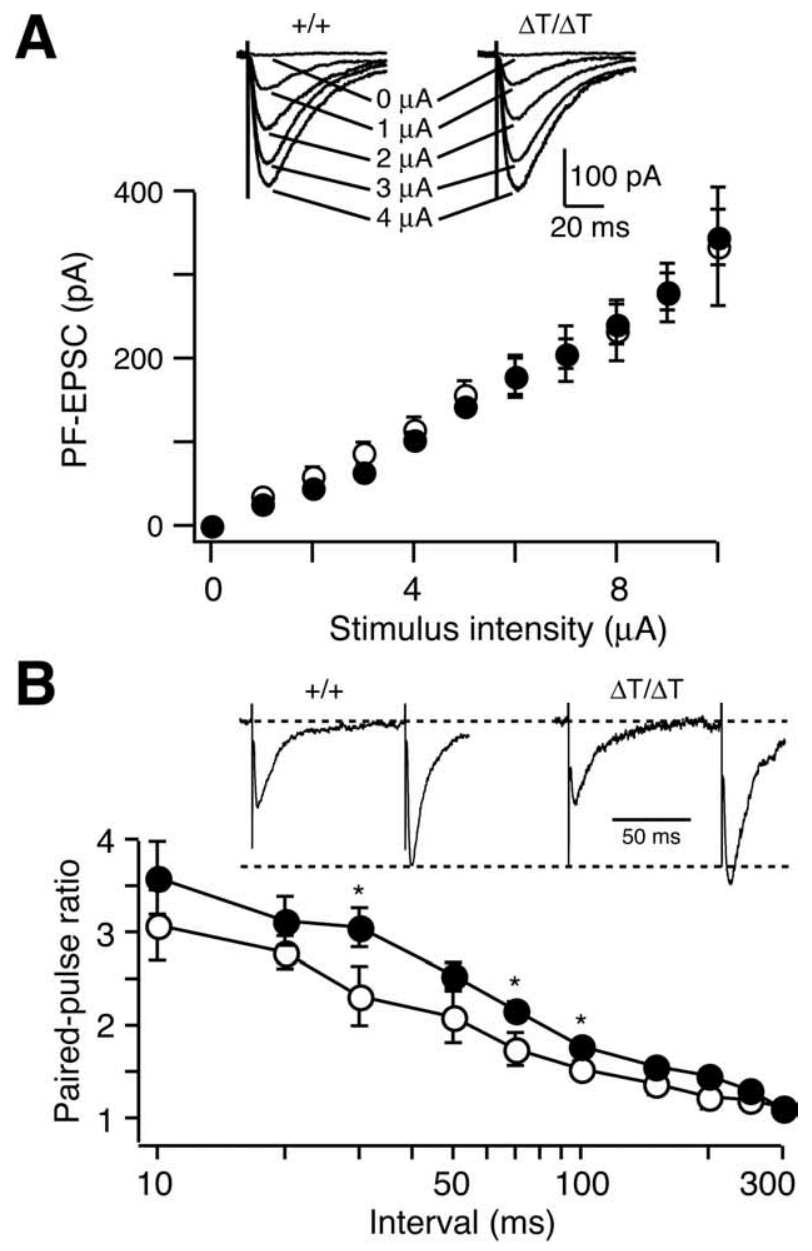

C

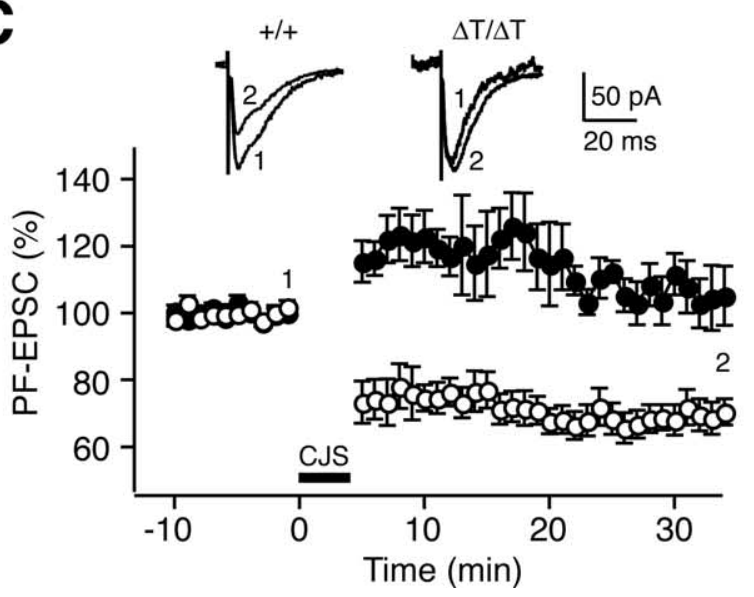

Figure 5. Impairment of cerebellar long-term depression in GluR $\delta 2 \Delta \mathrm{T}$ mice. $\boldsymbol{A}$, Inputoutput relationship of the PF-EPSCS. Amplitudes of PF-EPSCS plotted as a function of stimulus intensity in the wild-type $(+/+$, open circles; $n=8)$ and GluR $\delta 2 \Delta \mathrm{T}(\Delta \mathrm{T} / \Delta \mathrm{T}$, filled circles; $n=6)$ PCs. Representative traces of PF-EPSCs with increasing stimulus intensities $(0-8 \mu \mathrm{A})$ recorded from wild-type and GluR $\delta 2 \Delta \mathrm{T} P(s$ are shown on the top. Membrane voltages were held at $-80 \mathrm{mV}$. B, PPR of PF-EPSCs recorded from PCs in wild-type (open circles; $n=5$ ) or GluR $\delta 2 \Delta \mathrm{T}$ (filled circles; $n=6$ ) mice at several interpulse intervals. PPRs in GluR $\delta 2 \Delta \mathrm{T}$ mice are slightly higher than those in wild-type mice at relatively shorter interpulse intervals. Representative traces of PF-EPSC in response to paired stimuli ( $100 \mathrm{~ms}$ interval) recorded from wild-type and GluR $\delta 2 \Delta T$ PCs are shown on the top. Membrane voltages were held at $-80 \mathrm{mV}$. C, Time course of changes in PF-EPSCs recorded from PCs in wild-type (open circles; $n=8$ ) or GluR $\delta 2 \Delta \mathrm{T}$ (filled circles; $n=5$ ) mice. After the conjunctive stimulation (CSS; bold horizontal bar) of PF and depolarization ( $1 \mathrm{~Hz}, 300$ s), typical LTD was induced in wild-type PCs but not in GluR $\delta 2 \Delta T$ PCS. Representative recordings of PF-EPSC before (1) or 30 min after (2) CJS are shown on the top. All values represent mean \pm SEM. ${ }^{*} p<0.05$, Student's $t$ test.

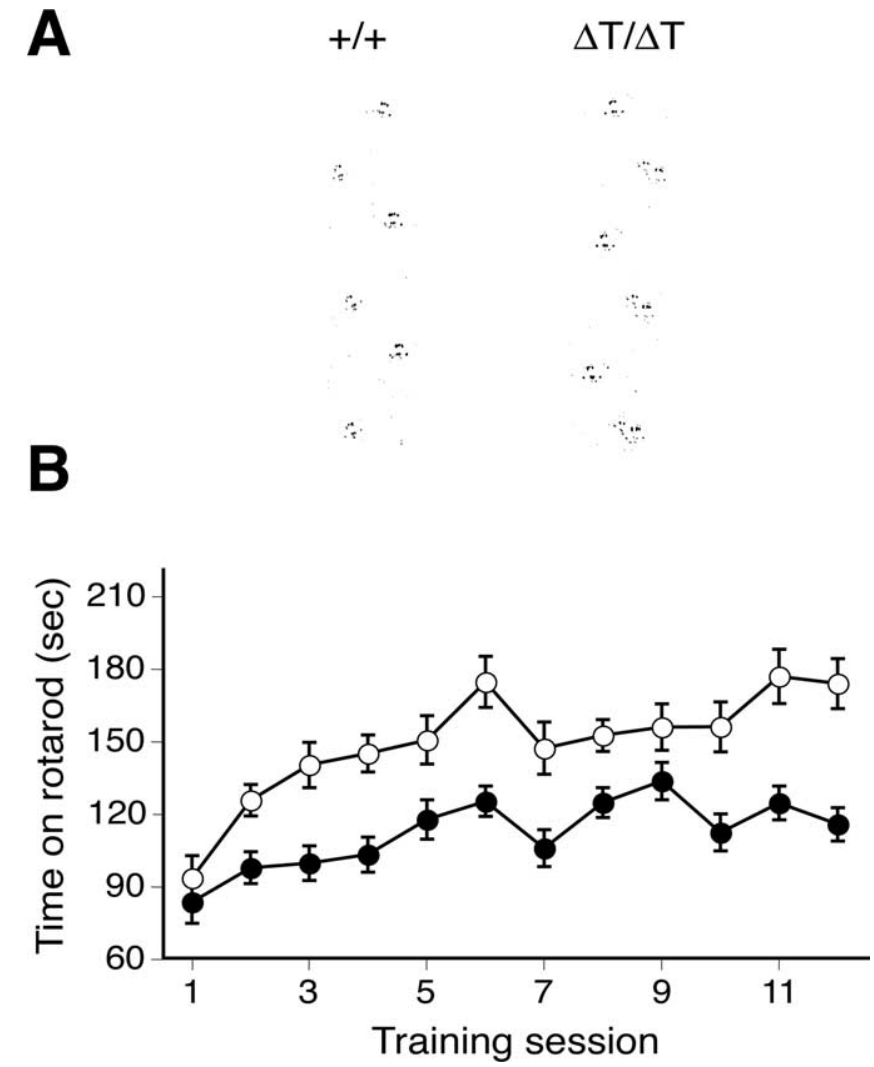

Figure 6. Footprint patterns and accelerating rotarod test. $A$, Representative footprint patterns from wild-type $(+/+)$ and GluR $\delta 2 \Delta \mathrm{T}(\Delta \mathrm{T} / \Delta \mathrm{T})$ mice. $\boldsymbol{B}$, Accelerating rotarod test. Time that mice remained on an accelerating rotarod before falling was measured as a function of training session. Open and filled circles represent wild-type $(n=21)$ and GluR $\delta 2 \Delta \mathrm{T}(n=27)$ mice, respectively. All values represent mean \pm SEM.

monoinnervation of PCs by CFs is established in wild-type mice from morphological view points. These results are consistent with previous observations that most PCs become monoinnervated by single CFs by the end of the third postnatal week in wild-type mice (Crépel, 1982; Hashimoto and Kano, 2005). Furthermore, the CF innervation territory was restricted up to the border of proximal and distal dendrites of the target PCs (Fig. $8 B)$.

In GluR $\delta 2 \Delta \mathrm{T}$ mice, proximal dendrites of a given PC were innervated by either DTR/VGluT2-double-labeled or VGluT2single-labeled CFs, similarly to those in wild-type mice. However, in contrast to wild-type mice, CFs in GluR $\delta 2 \Delta \mathrm{T}$ mice extended their terminals beyond the proximal-to-distal border to innervate distal dendrites of the target PCs and often jumped aberrantly to innervate distal dendrites of nearby PCs (Fig. 9). As shown in Figure 9, $A$ and $B$, a proximal dendrite of $\mathrm{PC} 1$ was innervated by CF1 (red), whereas a distal dendrite stemming from this proximal dendrite was innervated by CF2 (green arrows). In another case shown in Figure $9 C$, a proximal dendrite of PC2 was innervated mainly by CF2 (bottom green arrows), but a distal dendrite stemming from this proximal dendrite of PC2 was innervated by a collateral emitting from CF1 that mainly innervated the adjacent PC1 (bottom red arrow). Furthermore, a distal dendrite of PC1 was also innervated by CF2 (Fig. 9C, top green arrows). These results suggest that, although single main CFs innervate the proximal dendrites of PCs, additional CFs frequently form ectopic innervation to distal dendrites of the same PCs. Consistently, by serial electron microscopy, some typical 
A
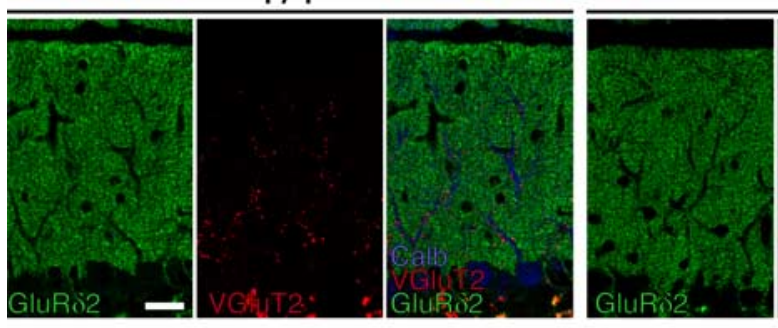

$\Delta \mathrm{T} / \Delta \mathrm{T}$

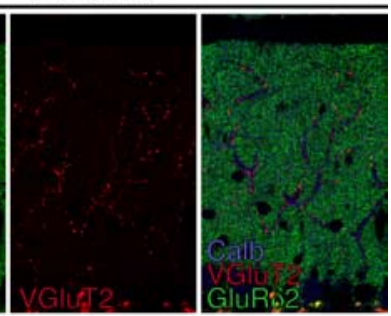

B
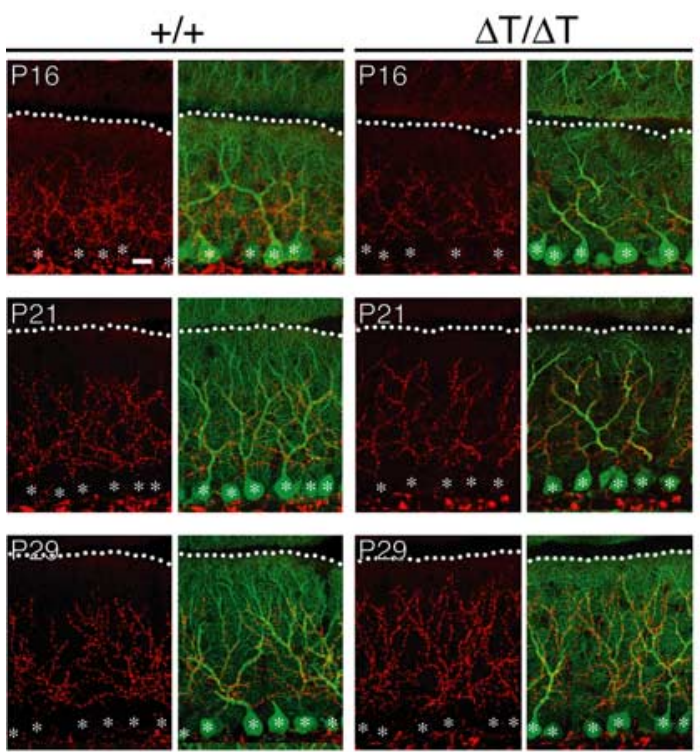

C
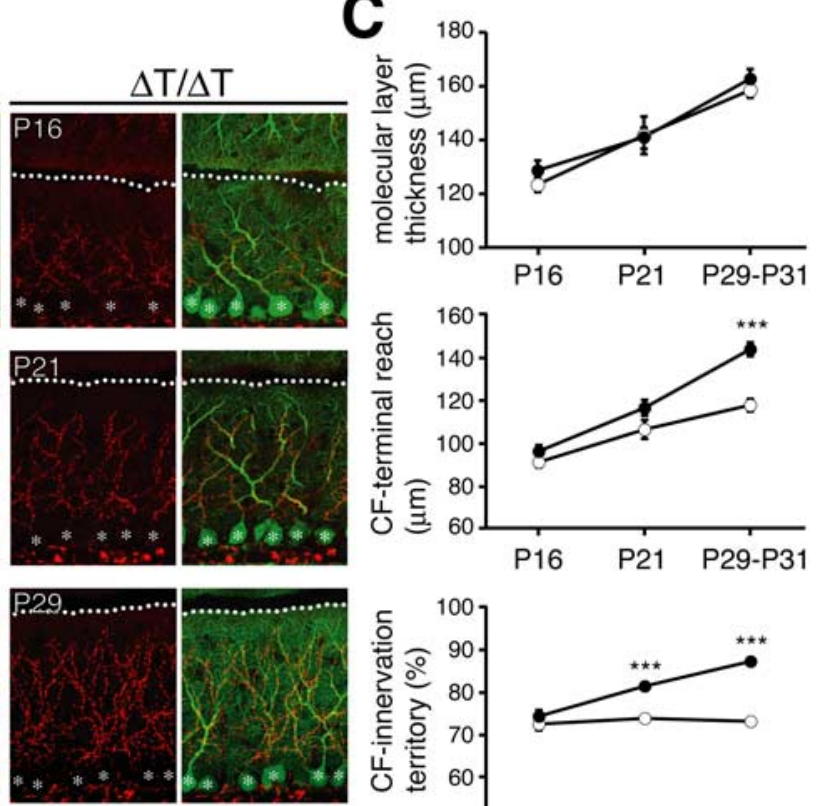



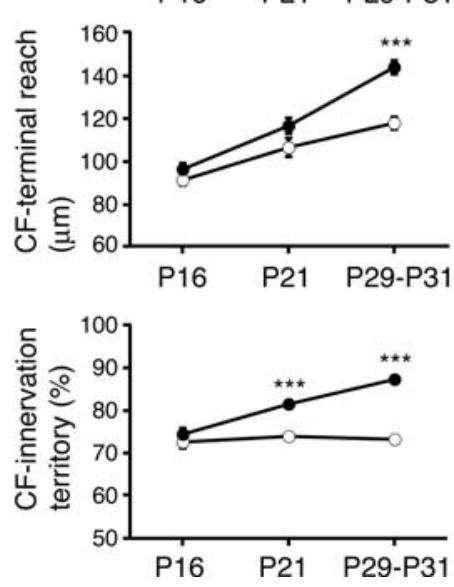

Figure 7. Distal extension of (F innervation territory in GluR $\delta 2 \Delta \mathrm{T}$ mice. $\boldsymbol{A}$, Cerebellar sections of wild-type $(+/+)$ and GluR $\delta 2 \Delta \mathrm{T}(\Delta \mathrm{T} / \Delta \mathrm{T})$ mice were triple immunostained with anti-GluR $\delta 2$ antibody (green), anti-VGluT2 antibody (red), and anti-calbindin antibody (blue). Triple-immunostained sections are shown as merged images (right panels) or separate images (left and middle panels). Calbindin, A marker for PC; VGluT2, a marker for CF terminals. B, Developmental change of CF territory in wild-type and GluR $\delta 2 \Delta T$ mice. Cerebellar sections of wild-type and GluR $\delta 2 \Delta T$ mice were double immunostained with antiVGluT2 antibody (red) and anti-calbindin antibody (green) at P16, P21, and P29-P31, respectively. Representative images of double-immunostained sections are shown as merged images (right panels) or separate images (left panels). Dotted lines in $\boldsymbol{B}$ indicate the pial surface. Asterisks in $\boldsymbol{B}$ indicate the soma of PCs. Scale bars: $\boldsymbol{A}, 50 \mu \mathrm{m} ; \boldsymbol{B}, 20 \mu \mathrm{m}$. $\boldsymbol{C}$, Quantitative analysis of $C F$ territory in wild-type (open circles; $n=9$ ) and GluR $\delta 2 \Delta \mathrm{T}$ (filled circles; $n=9$ ) mice. Developmental change of molecular layer thickness, CF-terminal reach, and CF innervation territory are shown in top, middle, and bottom, respectively. All values represent mean \pm SEM $(n=9) .{ }^{* * *} p<0.001$, Student's $t$ test.

distal dendrites of PCs in GluR $\delta 2 \Delta \mathrm{T}$ mice were found to have both PF-innervating spines and CF-innervating ones (supplemental Fig. 2, available at www.jneurosci.org as supplemental material). Thus, ectopic CF innervation at the distal dendritic compartment is a distinct feature of GluR $\delta 2 \Delta \mathrm{T}$ mice.

\section{CF-EPSCs with slow kinetics}

We next analyzed CF-EPSCs, which were identified from their characteristics, such as a clearly discernible current elicited in an all-or-none manner and paired-pulse depression (Konnerth et al., 1990). PCs are innervated by multiple CFs in early postnatal days, but most PCs become monoinnervated by single CFs by the end of the third postnatal week by the elimination of supernumerary CFs (Crépel, 1982; Hashimoto and Kano, 2005). In wildtype mice, $78 \%$ of PCs ( 25 of 32) were innervated by single CFs. The rest (seven PCs) had one supernumerary CF in addition to the main CF. The main CF-EPSCs had much larger amplitudes than the surplus CF-EPSCs, although the two types of CF-EPSC were comparable in terms of kinetics (Fig. 10A).

In GluR $\delta 2 \Delta \mathrm{T}$ mice, $33 \%$ of PCs ( 11 of 33) were singly innervated by a $\mathrm{CF}$, and the majority had one or two supernumerary CFs in addition to the main CF (Fig. 10A). No significant differences were found in the amplitude of the main CFs between wild-type and GluR $\delta 2 \Delta \mathrm{T}$ mice as well as in that of surplus CF-EPSCs (Fig. $10 B$, left). There was no significant difference in the reversal potential of CF-EPSC between wild-type and GluR $\delta 2 \Delta \mathrm{T}$ PCs (data not shown). However, both the rise and decay times of CF-EPSCs were significantly longer in GluR $\delta 2 \Delta \mathrm{T}$ mice than in wild-type mice (Fig. $10 A, B$, middle and right). The slower time course of the main CF-EPSCs with large amplitudes in GluR $\delta 2 \Delta \mathrm{T}$ mice may be ascribed to the distal extension of CF innervation (Figs. 7, 9) (supplemental Fig. 1, available at www.jneurosci.org as supplemental material). Furthermore, some surplus CF-EPSCs in GluR $\delta 2 \Delta \mathrm{T}$ mice (Fig. 10C, above the bold horizontal line) had rise time longer than $5 \mathrm{~ms}$ and decay time longer than $45 \mathrm{~ms}$ (Fig. $10 A, C)$, whereas all the main CF-EPSCs in GluR $\delta 2 \Delta \mathrm{T}$ mice showed rise time shorter than $5 \mathrm{~ms}$ and decay time shorter than 45 ms. Thus, surplus CF-EPSCs in GluR $\delta 2 \Delta \mathrm{T}$ mice can be divided into two groups according to their kinetics (Fig. 10C). Atypical CF-EPSCs with slower kinetics represented surplus CF-EPSCs in GluR $\delta 2 \Delta$ T mice (Fig. 10C, above the bold horizontal line) that showed much slower kinetics than the main CF-EPSCs, whereas surplus CF-EPSCs with faster kinetics had kinetics comparable with those of the main CF-EPSCs. Two populations of CF-EPSCs with different kinetics were also found in GluR $\delta 2$ null mutant mice. Atypical CF-EPSCs with slow kinetics in GluR $\delta 2$ null mutant mice were ascribed to ectopic CF innervation to neighboring PCs (Hashimoto et al., 2001; Ichikawa et al., 2002). Thus, PCs of GluR $\delta 2 \Delta$ T mice could be classified into four categories by the pattern of CF innervation. The first group of PCs was innervated by a single main $\mathrm{CF}$, which generated CF-EPSCs with faster kinetics (11 of 33 PCs). The second group of PCs was innervated by one main CF with faster kinetics and also by one or more surplus CFs with slower kinetics generating atypical CF-EPSCs (15 of 33 PCs). The third pattern was the innervation of PCs by one main CF with faster kinetics and one surplus CF with faster kinetics ( 5 of 33 PCs). The fourth pattern was the innervation of PCs by one main CF with faster kinetics, one surplus CF with faster kinetics, and another surplus CF with slower kinetics (2 of 33 PCs). Thus, atypical CF-EPSCs with slower kinetics significantly contributed to the high percentage of surplus CF innervation to PCs in GluR $\delta 2 \Delta \mathrm{T}$ mice (Fig. 10D).

In addition to the existence of ectopic CF synapses at distal 
dendrites, failure in the elimination of surplus CF synapses at proximal dendrites was observed in GluR $\delta 2$ null mutant mice (Kashiwabuchi et al., 1995; Hashimoto et al., 2001). Thus, we finally examined whether the deletion of the $\mathrm{T}$ site of GluR $\delta 2$ affects the elimination of surplus CF synapses at proximal dendrites during development. When atypical CFEPSCs with slower kinetics that most likely represent ectopic innervation at distal dendrites (Fig. 10C, above the bold horizontal line) were omitted, most PCs had a single CF-EPSC, and the rest had one main CF-EPSC with a large amplitude and one surplus CF-EPSC with a small amplitude (Fig. $10 D$, right). As regards CF-EPSCs with faster kinetics, the ratios of singly to multiply innervated PCs were comparable between wild-type and GluR $\delta 2 \Delta \mathrm{T}$ mice (Fig. $10 \mathrm{D}$, right). In contrast, the ratio was higher in GluR $\delta 2$ or mGluR1 null mutant mice than in wild-type mice (Hashimoto et al., 2001), suggesting the failure of surplus CF elimination at proximal dendrites in these mutant mice. These results suggest that the innervation pattern of CFs with faster EPSCs in GluR $\delta 2 \Delta \mathrm{T}$ mice is similar to that in wild-type mice but is different from those in GluR $\delta 2$ and mGluR1 null mutant mice.

\section{Discussion}

Here, we generated GluR $\delta 2 \Delta \mathrm{T}$ mice carrying mutant GluR $\delta 2$ lacking the T site comprising seven amino acids at the $\mathrm{C}$ terminal. There were no significant differences in the amount of receptor proteins in the PSD fraction and in the density of GluR $\delta 2$ immunogold particles at PF-PC synapses
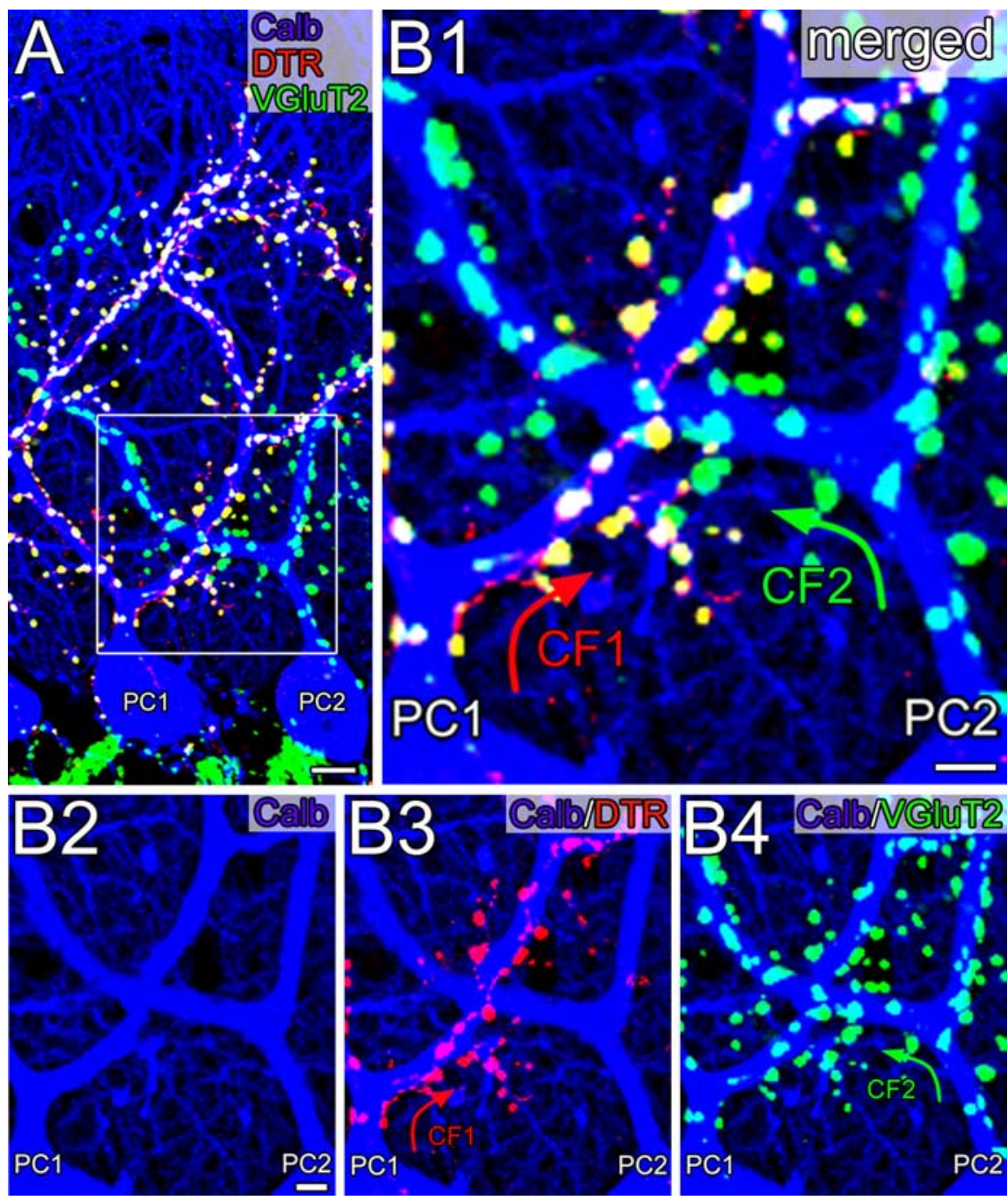

Figure 8. Triple fluorescent labeling showing mono-CF innervation in wild-type PCs. $A, B$, Triple-labeling images for DTR (red), VGluT2 (green), and calbindin (Calb; blue) are shown as merged low-power images ( $A$ ) and high-power images with merged (B1) and separate images (B2-B4). CF1 and CF2 represent DTR/VGluT2 double-labeled or VGluT2 single-labeled CF, respectively. PC1 and PC2 receive mono-CF innervation by CF1 and CF2, respectively. Scale bars: $A, 10 \mu \mathrm{m} ; \boldsymbol{B}, 5 \mu \mathrm{m}$.

between wild-type and GluR $\delta 2 \Delta \mathrm{T}$ mice.

Thus, the C-terminal truncation had little effect on the synaptic localization of receptor proteins, and GluR $\delta 2 \Delta \mathrm{T}$ mouse should be a valuable tool for studying the role of the $\mathrm{T}$ site in diverse GluR $\delta 2$ functions. PF-PC synaptic connection is critically dependent on GluR $\delta 2$ in both developing and adult cerebella (Kashiwabuchi et al., 1995; Kurihara et al., 1997; Takeuchi et al., 2005). The direct relationship between GluR $\delta 2$ density and synaptic contact suggests that postsynaptic GluR $\delta 2$ is essential for the maintenance of the presynaptic active zone, possibly by a physical linkage between the active zone and the postsynaptic GluR $\delta 2$ complex (Takeuchi et al., 2005). Synaptic connections between PF terminals and PC spines were intact in GluR $\delta 2 \Delta \mathrm{T}$ mutant mice as revealed by electron microscopy. Thus, the interactions between the T site of GluR $\delta 2$ and PSD proteins such as PSD-93 appear to be dispensable for PF-PC synapse formation. Consistently, there were no detectable alterations in structures at PF-PC synapses in PSD-93 mutant mice (McGee et al., 2001).

However, LTD induction at PF-PC synapses was impaired in GluR $\delta 2 \Delta \mathrm{T}$ mice. Correspondingly, the improvement in the performance of mutant mice in the accelerating rotarod test was less than that of wild-type mice. The impairment of motor learning in cerebellar LTD-deficient mutant mice was reproducibly observed (Ito, 2006). Although GluR $\delta 2$ null mutant mice were strongly ataxic, GluR $\delta 2 \Delta \mathrm{T}$ mice showed no ataxic gait and could walk along a straight line as wild-type mice did. The essential role of the GluR $\delta 2$ C terminal in cerebellar LTD is consistent with the observation that PTPMEG mutant mice showed impairment of cerebellar LTD induction (Kina et al., 2007). In contrast, controversial results were reported on the requirement of GluR $\delta 2 \mathrm{C}$ terminal for LTD induction by cDNA transfection studies in cultured PCs and cerebellar slices (Yawata et al., 2006; Kohda et al. 2007).

It has been well established since Cajal (1911) that different classes of inputs are not randomly intertwined along target neurons; rather, they are organized along restricted and in some cases highly discrete subcellular compartments. PC dendrites are characterized by proximal and distal compartments, on which CFs and PFs impinge, respectively (Larramendi and Victor, 1967; Palay and Chan-Palay, 1974). Several studies suggested the competitive formation of the innervation territory between CF and PF (Bravin et al., 1999; Morando et al., 2001; Ichikawa et al., 2002; Cesa et al., 2003, 2007). The proper formation of PF-PC synapses 

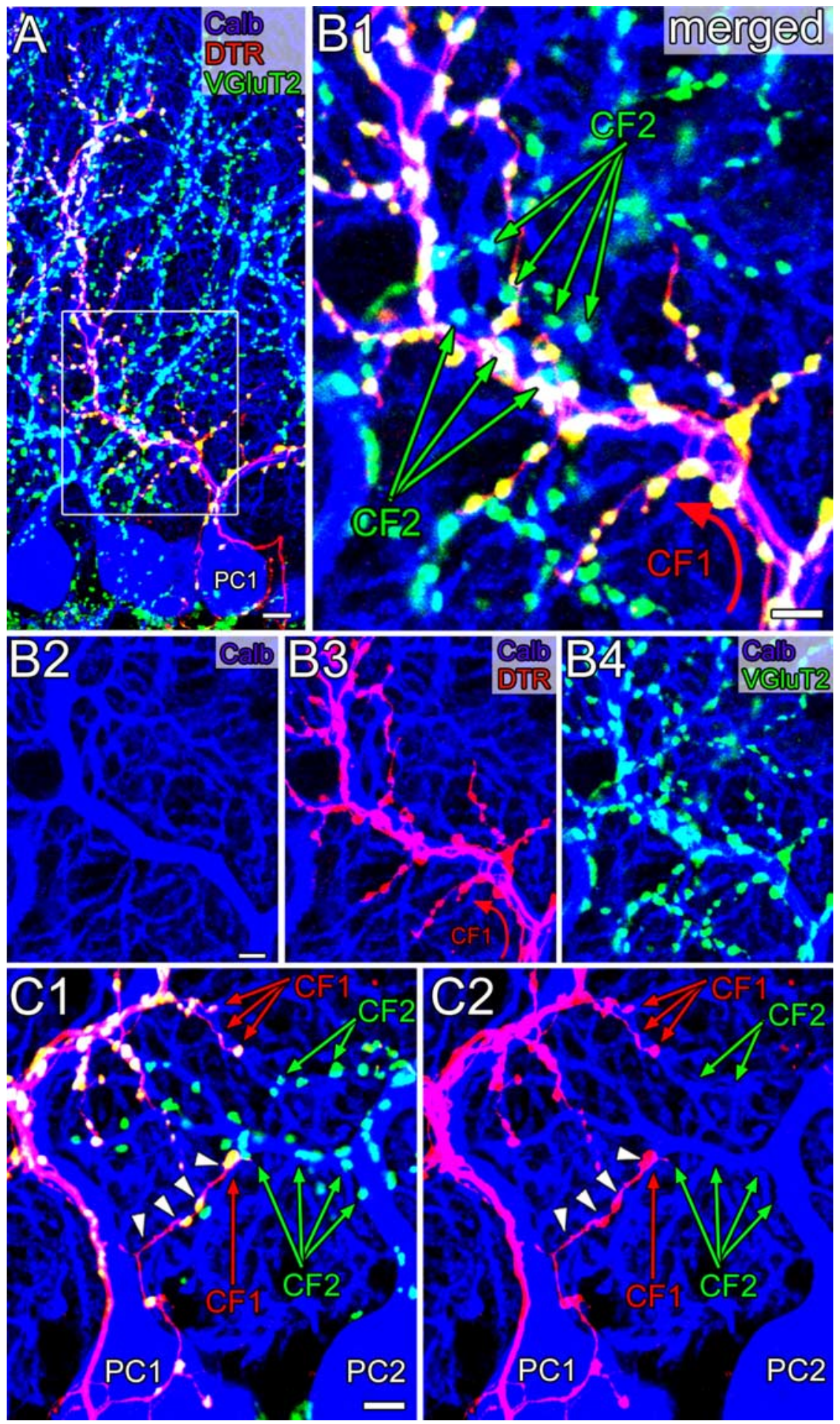

Figure 9. Triple fluorescent labeling showing ectopic CF innervation in GluR $\delta 2 \Delta T P C$. $\boldsymbol{A}$-C , Triple-labeling images for DTR (red), VGluT2 (green), and calbindin (blue) are shown as merged low-power images $(\boldsymbol{A})$ and high-power images with merged $(B 1, C 1)$ and separate images (B2-B4, C2). CF1 and CF2 represent DTR/VGluT2 double-labeled or VGluT2 single-labeled CF, respectively. Multiple (F innervation occurs in the boxed region in $\boldsymbol{A}$, which is enlarged in $\boldsymbol{B 1 - B 4}$. Proximal dendrites mainly innervated by (F1 receive additional innervation by (F2 at their distal dendrites (green arrows). $\boldsymbol{C}$, Another example of multiple CF innervation. A collateral of CF1 innervating PC1 invades a distal dendrite of PC2 (bottom red arrow), resulting in multiple CF innervation. Trajectory of the CF1 collateral is indicated by arrowheads. Furthermore, PC1 receives additional innervation by (F2 at distal dendrites (top green arrows). Scale bars: $A, 10 \mu \mathrm{m} ; \boldsymbol{B}, \boldsymbol{C}, 5 \mu \mathrm{m}$.

seems to be necessary for restricting CF innervation to proximal dendrites of PC (Kashiwabuchi et al., 1995; Kurihara et al., 1997; Zagrebelsky and Rossi, 1999; Ichikawa et al., 2002, Hirai et al., 2005). In GluR $\delta 2 \Delta \mathrm{T}$ mice, we found that the territory of CF innervation expanded distally to spiny branchlets by the VGluT2 immunostaining of CF terminals and anterograde CF labeling. Furthermore, CFs often extended their axon terminals over their target PCs to adjacent spiny branchlets of neighboring PCs, resulting in ectopic CF innervation. Thus, CF territory expansion and ectopic innervation are characteristic features of GluR $\delta 2 \Delta \mathrm{T}$ mice. Correspondingly, CF-EPSCs with small amplitudes and slow kinetics were found specifically in GluR $\delta 2 \Delta \mathrm{T}$ mice, whereas the populations of CF-EPSCs with fast kinetics were comparable between wild-type and mutant mice. Previous studies suggested that similar atypical CF-EPSCs with small amplitudes and slow kinetics observed in GluR $\delta 2$ null mutant mice are ascribed to ectopic CF innervation to neighboring PCs (Hashimoto et al., 2001; Ichikawa et al., 2002). Thus, CFEPSCs with small amplitudes and slow kinetics in GluR $\delta 2 \Delta \mathrm{T}$ mice are also likely to correspond to ectopic CF synapses at distal dendrites.

The distal extension of the CF innervation territory was also reported in GluR $\delta 2$ and cerebellin 1 precursor protein Cbln 1 null mutant mice (Ichikawa et al., 2002; Hirai et al., 2005). Because nearly half of the spines were not in contact with PF terminals in these mutant mice, a one-sided decrease in the number of PF-PC synapses appeared to result in the expansion of CF innervation territory through the heterosynaptic competition between PF and CF synapses. In contrast to these null mutant mice, $\mathrm{PF}-\mathrm{PC}$ synaptic connections were intact and PF synaptic transmission appeared to be normal in GluR $\delta 2 \Delta \mathrm{T}$ mice. Thus, our results suggest that the expansion of CF innervation territory does not necessarily require a decrease in the number of PF-PC synapses or the appearance of free spines. Instead, the distal extension and ectopic innervation of $\mathrm{CF}$ axon terminals in GluR $\delta 2 \Delta \mathrm{T}$ mice should be ascribed to the impairment of the signaling through the $\mathrm{C}$ terminal T site of GluR $\delta 2$ because GluR $\delta 2$ is localized at PF-PC synapses but not at CF synapses (Takayama et al., 1996; Landsend et al., 1997). Thus, these results suggest that the regulation of CF innervation territory by signaling through the T site of GluR $\delta 2$ at $\mathrm{PF}-\mathrm{PC}$ synapses underlies the heterosynaptic competition between PF and CF in PC. Morphologically, the presence of CF synapses seems to exclude nearby PF-PC contact (Llinás and Walton, 1998). After blocking electrical activity by tetrodotoxin, CF terminal arbors retracted from the proximal dendrites and the CF innervation territory decreased (Bravin et al., 1999; Morando et al., 2001). PF inputs, normally distributed on the spines of the distal dendrite, formed ectopic synapses on the proximal dendrite under the condition of electrical activity block. Decrease in 
CF innervation territory and ectopic formation of PF synapses at proximal dendrites were also observed in mutant mice lacking the VDCC $\alpha 1 \mathrm{~A}$ subunit (Miyazaki et al., 2004). Functionally active CFs exerted repressive action on the dendritic domain surrounding their synapses through the ionotropic AMPA receptor as a kind of lateral inhibition (Cesa and Strata, 2005; Cesa et al., 2007). These observations suggest that, at proximal dendrites, PF synapses are repressed by the activity of $\mathrm{CFs}$ that generate strong excitation and $\mathrm{Ca}^{2+}$ influx to $\mathrm{PC}$ dendrites. To compete against this mechanism, signaling through the $\mathrm{T}$ site of GluR $\delta 2$, most likely by protein-protein interactions, may be required for restricting the CF synapse territory to proximal dendrites. The topographical distributions of different classes of synaptic inputs are well exemplified in several neurons, including granule cells in the dentate gyrus, interneurons in the hippocampus, and thalamocortical relay cells (Freund and Buzsáki, 1996; Erisir et al., 1997; Förster et al., 2006). Extracellular matrix molecules play an important role in the proper lamination specificity of entorhinal fiber growth into the outer molecular layer in the dentate gyrus (Förster et al., 2001; Zhao et al., 2003). In the cerebellum, the targeting of GABAergic synapses on axon initial segment of PCs is regulated by the ankyrin-based subcellular gradient of neurofascin186, an L1 family Ig cell adhesion molecule (Ango et al., 2004).

In early development, PCs are innervated by multiple CFs. Then a single CF input is selected, allowed to mature, and strengthened, whereas surplus CFs are eliminated by the end of the third postnatal week in mice (Crépel, 1982; Hashimoto and Kano, 2005). In mGluR1 null mutant mice, most PCs remained to be multiply innervated by CFs with fast kinetics in the adulthood (Hashimoto et al., 2001), suggesting the failure of CF elimination from proximal dendrites. Similarly, the multiple innervation of PCs by CFs with fast kinetics was sustained in GluR $\delta 2$ null mutant mice. In contrast, the ratios of single to multiple innervations by CFs with fast kinetics were similar between wild-type and GluR $\delta 2 \Delta \mathrm{T}$ mice (Fig. 10D). Thus, surplus CFs appeared to have been successfully eliminated from proximal dendrites in GluR $\delta 2 \Delta \mathrm{T}$ mice.

The present study with GluR $\delta 2 \Delta \mathrm{T}$ mice provides evidence that diverse GluR $\delta 2$ functions are mediated by the distinct domains of GluR $\delta 2$. The C-terminal T site of GluR $\delta 2$ is essential for LTD induction at PF-PC synapses and the proper restriction of the CF territory but is dispensable for PF-PC synaptic connection

B $\left(p=0.86, \chi^{2}\right.$ test $)$.
A Main CF-EPSCs (M)


Surplus CF-EPSCs (S)
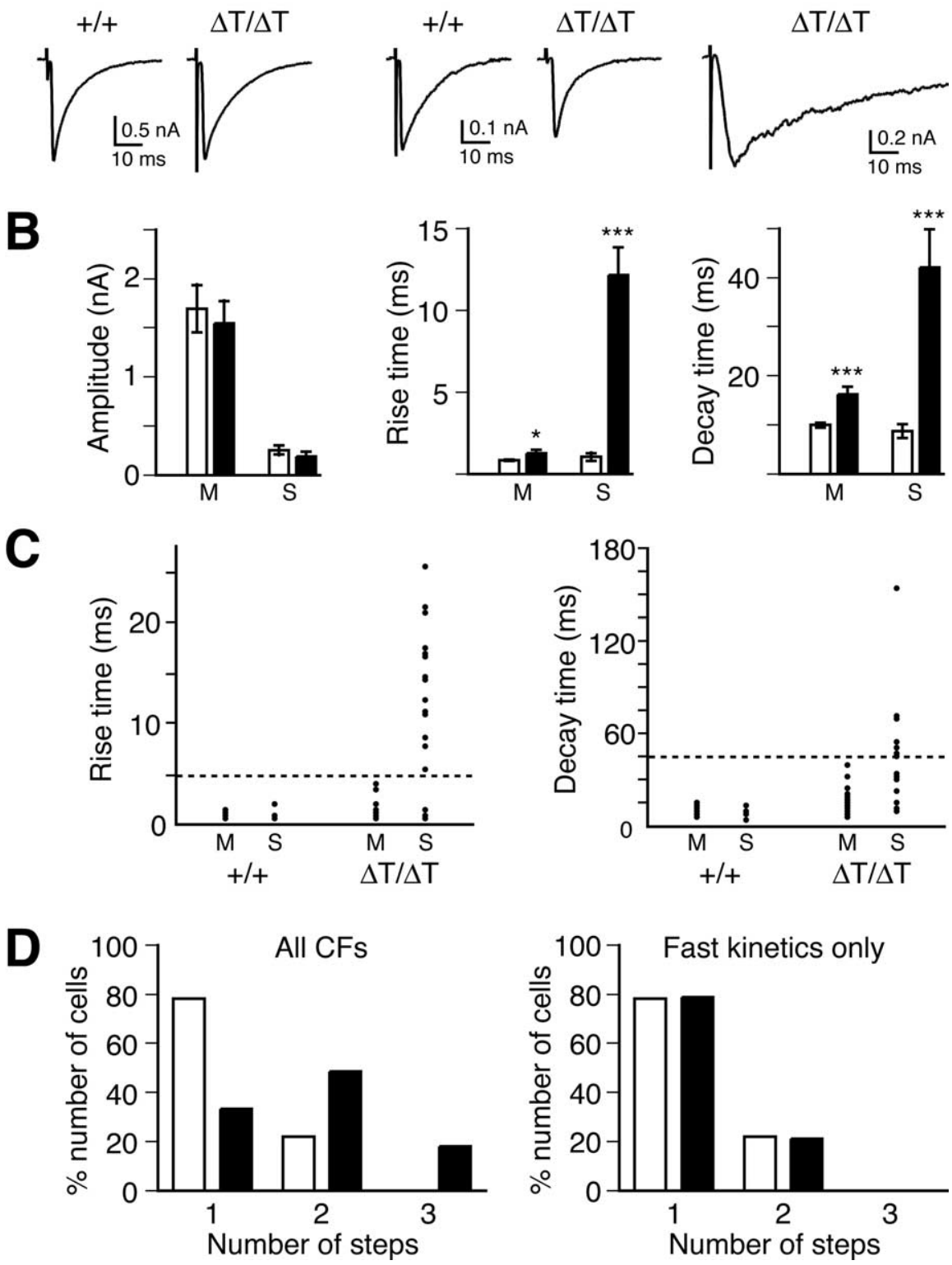

Figure 10. (F-EPSCs in GluR $\delta 2 \Delta \mathrm{T}$ mice have slower time course. $\boldsymbol{A}$, Representative recordings of CF-EPSCs from wild-type $(+/+)$ and GluR $\delta 2 \Delta T(\Delta T / \Delta T)$ mice. EPSCs recorded from PCs in both genotypes were divided into two categories, main CF-EPSCS (M) of singly or multiply innervated PCS and surplus CF-EPSCS (S) of multiply innervated PCs. Some surplus CF-EPSCS from GluR $\delta 2 \Delta$ T mice (right) show slower time course than other CF-EPSCs. Membrane voltages were held at $-20 \mathrm{mV}$ except for surplus CF-EPSCs with slower time course from GluR $\delta 2 \Delta \mathrm{T}$ mice ( $-80 \mathrm{mV}$ ). $\boldsymbol{B}$, Amplitude, $10-90 \%$ rise time, and decay time constant of CF-EPSCs recorded from wild-type PCs (open column; $M, n=32 ; \mathrm{S}, n=7$ ) and GluR $\delta 2 \Delta \mathrm{TPCs}$ (filled column; $\mathrm{M}, n=$ $33 ; S, n=25)$. All values represent mean \pm SEM. ${ }^{*} p<0.05 ;{ }^{* * *} p<0.001$, Student's $t$ test. $C$, Distribution of CF-EPSCs plotted by rise time (left) and decay time (right). CF-EPSCs with rise time longer than $5 \mathrm{~ms}$ and decay time longer than $45 \mathrm{~ms}$ are found only in surplus CF-EPSCs of GluR $\delta 2 \Delta$ T mice. D, Frequency histograms of PCs in terms of the number of discrete CF-EPSC steps from wild-type (open column; $n=32$ ) and GluR $\delta 2 \Delta \mathrm{T}$ (filled column; $n=33$ ) mice. When all CF-EPSCs were taken into account (left), the distribution was significantly different between wild-type and GluR $\delta 2 \Delta \operatorname{TPC}\left(p<0.0001, \chi^{2}\right.$ test). However, when the slow CF-EPSCs (data distributed above bold horizontal line in $C$ ) were eliminated (right), no significant difference was seen

and the elimination of surplus CF synapses at proximal dendrites during development.

\section{References}

Altman J, Bayer SA (1997) Development of the cerebellar system. Boca Raton, FL: CRC.

Ango F, di Cristo G, Higashiyama H, Bennett V, Wu P, Huang ZJ (2004) 
Ankyrin-based subcellular gradient of neurofascin, an immunoglobulin family protein, directs GABAergic innervation at Purkinje axon initial segment. Cell 119:257-272.

Araki K, Meguro H, Kushiya E, Takayama C, Inoue Y, Mishina M (1993) Selective expression of the glutamate receptor channel $\delta 2$ subunit in cerebellar Purkinje cells. Biochem Biophys Res Commun 197:1267-1276.

Boyden ES, Katoh A, Raymond JL (2004) Cerebellum-dependent learning: the role of multiple plasticity mechanisms. Annu Rev Neurosci 27:581-609.

Bravin M, Morando L, Vercelli A, Rossi F, Strata P (1999) Control of spine formation by electrical activity in the adult rat cerebellum. Proc Natl Acad Sci USA 96:1704-1709.

Cajal SR (1911) Histologie du système nerveux de l'homme et des vertébrés. Paris: Maloine.

Carlin RK, Grab DJ, Cohen RS, Siekevitz P (1980) Isolation and characterization of postsynaptic densities from various brain regions: enrichment of different types of postsynaptic densities. J Cell Biol 86:831-845.

Cesa R, Strata P (2005) Axonal and synaptic remodeling in the mature cerebellar cortex. Prog Brain Res 148:45-56.

Cesa R, Morando L, Strata P (2003) Glutamate receptor $\delta 2$ subunit in activity-dependent heterologous synaptic competition. J Neurosci 23:2363-2370.

Cesa R, Scelfo B, Strata P (2007) Activity-dependent presynaptic and postsynaptic structural plasticity in the mature cerebellum. J Neurosci 27:4603-4611.

Cho KO, Hunt CA, Kennedy MB (1992) The rat brain postsynaptic density fraction contains a homolog of the Drosophila discs-large tumor suppressor protein. Neuron 9:929-942.

Christian KM, Thompson RF (2003) Neural substrates of eyeblink conditioning: acquisition and retention. Learn Mem 11:427-455.

Crawley JN (2000) What's wrong with my mouse: behavioral phenotyping of transgenic and knockout mice, pp 120-121. New York: Wiley.

Crépel F (1982) Regression of functional synapses in the immature mammalian cerebellum. Trends Neurosci 5:266-269.

Edwards FA, Konnerth A, Sakmann B, Takahashi T (1989) A thin slice preparation for patch-clamp recordings from neurones of the mammalian central nervous system. Pflügers Arch 414:600-612.

Erisir A, Van Horn SC, Bickford ME, Sherman SM (1997) Immunocytochemistry and distribution of parabrachial terminals in the lateral geniculate nucleus of the cat: a comparison with corticogeniculate terminals. J Comp Neurol 377:535-549.

Förster E, Zhao S, Frotscher M (2001) Hyaluronan-associated adhesive cues control fiber segregation in the hippocampus. Development 128:3029-3039.

Förster E, Zhao S, Frotscher M (2006) Laminating the hippocampus. Nat Rev Neurosci 7:259-268.

Fremeau Jr RT, Troyer MD, Pahner I, Nygaard GO, Tran CH, Reimer RJ, Bellocchio EE, Fortin D, Storm-Mathisen J, Edwards RH (2001) The expression of vesicular glutamate transporters defines two classes of excitatory synapse. Neuron 31:247-260.

Freund TF, Buzsáki G (1996) Interneurons of the hippocampus. Hippocampus 6:347-470.

Fujiwara A, Kakizawa S, Iino M (2007) Induction of cerebellar long-term depression requires activation of calcineurin in Purkinje cells. Neuropharmacology 52:1663-1670.

Funabiki K, Mishina M, Hirano T (1995) Retarded vestibular compensation in mutant mice deficient in $\delta 2$ glutamate receptor subunit. NeuroReport 7:189-192.

Hashimoto K, Kano M (2005) Postnatal development and synapse elimination of climbing fiber to Purkinje cell projection in the cerebellum. Neurosci Res 53:221-228.

Hashimoto K, Ichikawa R, Takechi H, Inoue Y, Aiba A, Sakimura K, Mishina M, Hashikawa T, Konnerth A, Watanabe M, Kano M (2001) Roles of glutamate receptor $\delta 2$ subunit (GluR $\delta 2$ ) and metabotropic glutamate receptor subtype 1 (mGluR1) in climbing fiber synapse elimination during postnatal cerebellar development. J Neurosci 21:9701-9712.

Hirai H, Pang Z, Bao D, Miyazaki T, Li L, Miura E, Parris J, Rong Y, Watanabe M, Yuzaki M, Morgan JI (2005) Cbln1 is essential for synaptic integrity and plasticity in the cerebellum. Nat Neurosci 8:1534-1541.

Hironaka K, Umemori H, Tezuka T, Mishina M, Yamamoto T (2000) The protein-tyrosine phosphatase PTPMEG interacts with glutamate receptor $\delta 2$ and $\varepsilon$ subunits. J Biol Chem 275:16167-16173.
Ichikawa R, Miyazaki T, Kano M, Hashikawa T, Tatsumi H, Sakimura K, Mishina M, Inoue Y, Watanabe M (2002) Distal extension of climbing fiber territory and multiple innervation caused by aberrant wiring to adjacent spiny branchlets in cerebellar Purkinje cells lacking glutamate receptor $\delta 2$. J Neurosci 22:8487-8503.

Ito M (2006) Cerebellar circuitry as a neuronal machine. Prog Neurobiol 78:272-303.

Kakizawa S, Yamasaki M, Watanabe M, Kano M (2000) Critical period for activity-dependent synapse elimination in developing cerebellum. J Neurosci 20:4954-4961.

Kakizawa S, Miyazaki T, Yanagihara D, Iino M, Watanabe M, Kano M (2005) Maintenance of presynaptic function by AMPA receptor-mediated excitatory postsynaptic activity in adult brain. Proc Natl Acad Sci USA 102:19180-19185.

Kakizawa S, Kishimoto Y, Hashimoto K, Miyazaki T, Furutani K, Shimizu H, Fukaya M, Nishi M, Sakagami H, Ikeda A, Kondo H, Kano M, Watanabe M, Iino M, Takeshima H (2007) Junctophilin-mediated channel crosstalk essential for cerebellar synaptic plasticity. EMBO J 26:1924-1933.

Kashiwabuchi N, Ikeda K, Araki K, Hirano T, Shibuki K, Takayama C, Inoue Y, Kutsuwada T, Yagi T, Kang Y, Aizawa S, Mishina M (1995) Impairment of motor coordination, Purkinje cell synapse formation, and cerebellar long-term depression in GluR $\delta 2$ mutant mice. Cell 81:245-252.

Kina S, Tezuka T, Kusakawa S, Kishimoto Y, Kakizawa S, Hashimoto K, Ohsugi M, Kiyama Y, Horai R, Kakuta S, Iwakura Y, Iino M, Kano M, Manabe T, Yamamoto T (2007) Involvement of protein-tyrosine phosphatase PTPMEG in motor learning and cerebellar long-term depression. Eur J Neurosci, in press.

Kishimoto Y, Kawahara S, Suzuki M, Mori H, Mishina M, Kirino Y (2001) Classical eyeblink conditioning in glutamate receptor subunit $\delta 2$ mutant mice is impaired in the delay paradigm but not in the trace paradigm. Eur J Neurosci 13:1249-1253.

Kohda K, Kakegawa W, Matsuda S, Nakagami R, Kakiya N, Yuzaki M (2007) The extreme C-terminus of GluR $\delta 2$ is essential for induction of long-term depression in cerebellar slices. Eur J Neurosci 25:1357-1362.

Konnerth A, Llano I, Armstrong CM (1990) Synaptic currents in cerebellar Purkinje cells. Proc Natl Acad Sci USA 87:2662-2665.

Kurihara H, Hashimoto K, Kano M, Takayama C, Sakimura K, Mishina M, Inoue Y, Watanabe M (1997) Impaired parallel fiber-Purkinje cell synapse stabilization during cerebellar development of mutant mice lacking the glutamate receptor $\delta 2$ subunit. J Neurosci 17:9613-9623.

Lalouette A, Lohof A, Sotelo C, Guénet J-L, Mariani J (2001) Neurobiological effects of a null mutation depend on genetic context: comparison between two hotfoot alleles of the delta-2 ionotropic glutamate receptor. Neuroscience 105:443-455.

Landsend AS, Amiry-Moghaddam M, Matsubara A, Bergersen L, Usami S, Wenthold RJ, Ottersen OP (1997) Differential localization of $\delta$ glutamate receptors in the rat cerebellum: coexpression with AMPA receptors in parallel fiber-spine synapses and absence from climbing fiber-spine synapses. J Neurosci 17:834-842.

Larramendi LEM, Victor T (1967) Synapses on the Purkinje cell spines in the mouse. An electronmicroscopic study. Brain Res 5:15-30.

Llano I, Marty A, Armstrong CM, Konnerth A (1991) Synaptic- and agonist-induced excitatory currents of Purkinje cells in rat cerebellar slices. J Physiol (Lond) 434:183-213.

Llinás RR, Walton KD (1998) Cerebellum. In: The synaptic organization of the brain, Ed 4 (Shepherd GM, ed), pp 255-288. New York: Oxford.

Lomeli H, Sprengel R, Laurie DJ, Köhr G, Herb A, Seeburg PH, Wisden W (1993) The rat delta- 1 and delta-2 subunits extend the excitatory amino acid receptor family. FEBS Lett 315:318-322.

Matsuda I, Mishina M (2000) Identification of a juxtamembrane segment of the glutamate receptor $\delta 2$ subunit required for the plasma membrane localization. Biochem Biophys Res Commun 275:565-571.

Matsuda S, Hannen R, Matsuda K, Yamada N, Tubbs T, Yuzaki M (2004) The C-terminal juxtamembrane region of the $\delta 2$ glutamate receptor controls its export from the endoplasmic reticulum. Eur J Neurosci 19:1683-1690.

McGee AW, Topinka JR, Hashimoto K, Petralia RS, Kakizawa S, Kauer FW, Aguilera-Moreno A, Wenthold RJ, Kano M, Bredt DS (2001) PSD-93 knock-out mice reveal that neuronal MAGUKs are not required for development or function of parallel fiber synapses in cerebellum. J Neurosci 21:3085-3091. 
Mishina M, Sakimura K (2007) Conditional gene targeting on the pure C57BL/6 genetic background. Neurosci Res 58:105-112.

Miura E, Fukaya M, Sato T, Sugihara K, Asano M, Yoshioka K, Watanabe M (2006) Expression and distribution of JNK/SAPK-associated scaffold protein JSAP1 in developing and adult mouse brain. J Neurochem 97:1431-1446.

Miyagi Y, Yamashita T, Fukaya M, Sonoda T, Okuno T, Yamada K, Watanabe M, Nagashima Y, Aoki I, Okuda K, Mishina M, Kawamoto S (2002) Delphilin: a novel PDZ and formin homology domain-containing protein that synaptically colocalizes and interacts with glutamate receptor $\delta 2$ subunit. J Neurosci 22:803-814.

Miyazaki T, Fukaya M, Shimizu H, Watanabe M (2003) Subtype switching of vesicular glutamate transporters at parallel fibre-Purkinje cell synapses in developing mouse cerebellum. Eur J Neurosci 17:2563-2572.

Miyazaki T, Hashimoto K, Shin HS, Kano M, Watanabe M (2004) P/Q-type $\mathrm{Ca}^{2+}$ channel $\alpha 1 \mathrm{~A}$ regulates synaptic competition on developing cerebellar Purkinje cells. J Neurosci 24:1734-1743.

Mohrmann R, Köhr G, Hatt H, Sprengel R, Gottmann K (2002) Deletion of the $\mathrm{C}$-terminal domain of the NR2B subunit alters channel properties and synaptic targeting of $N$-methyl-D-aspartate receptors in nascent neocortical synapses. J Neurosci Res 68:265-275.

Morando L, Cesa R, Rasetti R, Harvey R, Strata P (2001) Role of glutamate $\delta$ - 2 receptors in activity-dependent competition between heterologous afferent fibers. Proc Natl Acad Sci USA 98:9954-9959.

Mori H, Manabe T, Watanabe M, Satoh Y, Suzuki N, Toki S, Nakamura K, Yagi T, Kushiya E, Takahashi T, Inoue Y, Sakimura K, Mishina M (1998) Role of the carboxy-terminal region of the GluRe2 subunit in synaptic localization of the NMDA receptor channel. Neuron 21:571-580.

Nakagawa S, Watanabe M, Isobe T, Kondo H, Inoue Y (1998) Cytological compartmentalization in the staggerer cerebellum, as revealed by calbindin immunohistochemistry for Purkinje cells. J Comp Neurol 395:112-120.

Namiki S, Kakizawa S, Hirose K, Iino M (2005) NO signalling decodes frequency of neuronal activity and generates synapse-specific plasticity in mouse cerebellum. J Physiol (Lond) 566:849-863.

Nolan MF, Malleret G, Lee KH, Gibbs E, Dudman JT, Santoro B, Yin D, Thompson RF, Siegelbaum SA, Kandel ER, Morozov A (2003) The hyperpolarization-activated HCN1 channel is important for motor learning and neuronal integration by cerebellar Purkinje cells. Cell 115:551-564.

Palay SL, Chan-Palay V (1974) Cerebellar cortex. Cytology and organization. New York: Springer.

Roche KW, Ly CD, Petralia RS, Wang YX, McGee AW, Bredt DS, Wenthold RJ (1999) Postsynaptic density-93 interacts with the $\delta 2$ glutamate receptor subunit at parallel fiber synapses. J Neurosci 19:3926-3934.

Steigerwald F, Schulz TW, Schenker LT, Kennedy MB, Seeburg PH, Köhr G (2000) C-Terminal truncation of NR2A subunits impairs synaptic but not extrasynaptic localization of NMDA receptors. J Neursci 20:4573-4581.
Takayama C, Nakagawa S, Watanabe M, Mishina M, Inoue Y (1996) Developmental changes in expression and distribution of the glutamate receptor channel $\delta 2$ subunit according to the Purkinje cell maturation. Brain Res Dev Brain Res 92:147-155.

Takeuchi T, Nomura T, Tsujita M, Suzuki M, Fuse T, Mori H, Mishina M (2002) Flp recombinase transgenic mice of C57BL/6 strain for conditional gene targeting. Biochem Biophys Res Commun 293:953-957.

Takeuchi T, Miyazaki T, Watanabe M, Mori H, Sakimura K, Mishina M (2005) Control of synaptic connection by glutamate receptor $\delta 2$ in the adult cerebellum. J Neurosci 25:2146-2156.

Taniguchi M, Yuasa S, Fujisawa H, Naruse I, Saga S, Mishina M, Yagi T (1997) Disruption of semaphorin III/D gene causes severe abnormality in peripheral nerve projection. Neuron 19:519-530.

Uemura T, Mori H, Mishina M (2004) Direct interaction of GluR $\delta 2$ with Shank scaffold proteins in cerebellar Purkinje cells. Mol Cell Neurosci 26:330-341.

Watanabe M, Fukaya M, Sakimura K, Manabe T, Mishina M, Inoue Y (1998) Selective scarcity of NMDA receptor channel subunits in the stratum lucidum (mossy fibre-recipient layer) of the mouse hippocampal CA3 subfield. Eur J Neurosci 10:478-487.

Yamada K, Fukaya M, Shimizu H, Sakimura K, Watanabe M (2001) NMDA

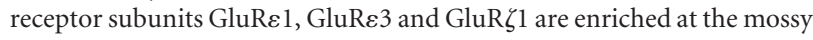
fibre-granule cell synapse in the adult mouse cerebellum. Eur J Neurosci 13:2025-2036.

Yamazaki M, Araki K, Shibata A, Mishina M (1992) Molecular cloning of a cDNA encoding a novel member of the mouse glutamate receptor channel family. Biochem Biophys Res Commun 183:886-892.

Yap CC, Muto Y, Kishida H, Hashikawa T, Yano R (2003) PKC regulates the $\delta 2$ glutamate receptor interaction with S-SCAM/MAGI-2 protein. Biochem Biophys Res Commun 301:1122-1128.

Yawata S, Tsuchida H, Kengaku M, Hirano T (2006) Membrane-proximal region of glutamate receptor $\delta 2$ subunit is critical for long-term depression and interaction with protein interacting with $\mathrm{C}$ kinase 1 in a cerebellar Purkinje neuron. J Neurosci 26:3626-3633.

Yue Z, Horton A, Bravin M, DeJager PL, Selimi F, Heintz N (2002) A novel protein complex linking the $\delta 2$ glutamate receptor and autophagy: implications for neurodegeneration in lurcher mice. Neuron 35:921-933.

Zagrebelsky M, Rossi F (1999) Postnatal development and adult organisation of the olivocerebellar projection map in the hypogranular cerebellum of the rat. J Comp Neurol 407:527-542.

Zhao S, Förster E, Chai X, Frotscher M (2003) Different signals control laminar specificity of commissural and entorhinal fibers to the dentate gyrus. J Neurosci 23:7351-7357.

Zucker RS, Regehr WG (2002) Short-term synaptic plasticity. Annu Rev Physiol 64:355-405.

Zuo J, De Jager PL, Takahashi KA, Jiang W, Linden DJ, Heintz N (1997) Neurodegeneration in Lurcher mice caused by mutation in $\delta 2$ glutamate receptor gene. Nature 388:769-773. 